\title{
Updated African biomass burning emission inventories in the framework of the AMMA-IDAF program, with an evaluation of combustion aerosols
}

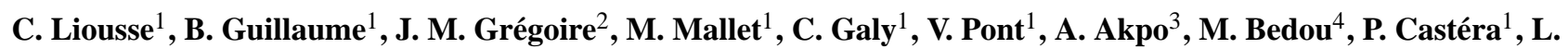

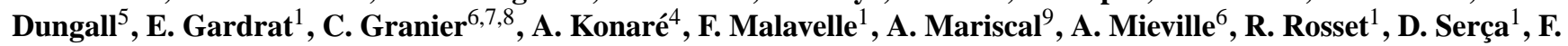 \\ Solmon $^{1}$, F. Tummon ${ }^{1}$, E. Assamoi ${ }^{1}$, V. Yoboué ${ }^{4}$, and P. Van Velthoven ${ }^{10}$ \\ ${ }^{1}$ Laboratoire d'Aérologie, Université de Toulouse, CNRS, UMR5560, 14 avenue Edouard Belin, 31400 Toulouse, France \\ ${ }^{2}$ Joint Research Centre (JRC) of the European Commission Institute for Environment and Sustainability (IES), Global \\ Environment Monitoring Unit (GEM), TP 440 - Via Fermi, 2749, 21027 Ispra (VA), Italy \\ ${ }^{3}$ Faculté des Sciences et Techniques, Université d'Abomey-Calavi, BP 07-0094, Cotonou, Benin \\ ${ }^{4}$ Université de Cocody Abidjan, UFR SSMT 22 bp 582 Abidjan 22, Ivory Coast \\ ${ }^{5}$ Faculté des Sciences - Département de Physique, B.P. 10662 Niamey, Niger \\ ${ }^{6}$ UPMC Univ. Paris 6; CNRS-INSU, LATMOS-IPSL, 75005 Paris, France \\ ${ }^{7}$ NOAA Earth System Research Laboratory, 80305-3337 Boulder, USA \\ ${ }^{8}$ Cooperative Institute for Research in Environmental Sciences, University of Colorado, 80309-0216 Boulder, USA \\ ${ }^{9}$ LGIT, Maison des Géosciences, 38400 Saint Martin d'Heres, France \\ ${ }^{10}$ KNMI (Royal Netherlands Meteorological Institute), Chemistry and Climate Division, P.O. Box 201, \\ 3730 AE De Bilt, The Netherlands
}

Received: 12 February 2010 - Published in Atmos. Chem. Phys. Discuss.: 22 March 2010

Revised: 16 September 2010 - Accepted: 29 September 2010 - Published: 11 October 2010

\begin{abstract}
African biomass burning emission inventories for gaseous and particulate species have been constructed at a resolution of $1 \mathrm{~km}$ by $1 \mathrm{~km}$ with daily coverage for the 2000 2007 period. These inventories are higher than the GFED2 inventories, which are currently widely in use. Evaluation specifically focusing on combustion aerosol has been carried out with the ORISAM-TM4 global chemistry transport model which includes a detailed aerosol module. This paper compares modeled results with measurements of surface BC concentrations and scattering coefficients from the AMMA Enhanced Observations period, aerosol optical depths and single scattering albedo from AERONET sunphotometers, LIDAR vertical distributions of extinction coefficients as well as satellite data. Aerosol seasonal and interannual evolutions over the 2004-2007 period observed at regional scale and more specifically at the Djougou (Benin) and Banizoumbou (Niger) AMMA/IDAF sites are well reproduced by our global model, indicating that our biomass burning emission inventory appears reasonable.
\end{abstract}

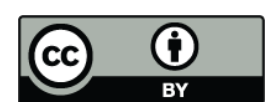

Correspondence to: C. Liousse (lioc@aero.obs-mip.fr)

\section{Introduction}

Western African aerosols are complex mixtures of combustion aerosols emitted from biomass burning (mainly savanna fires), domestic fires (fuelwood and charcoal), fossil fuel sources (traffic, industry), together with dust particles from the Sahel and Sahara (Liousse et al., 1996; Haywood et al., 2008). The temporal distribution of these sources is rather well known: open biomass burning aerosols are only produced during the dry season, whilst domestic fires for cooking as well as traffic and industrial aerosols are present throughout the year. Dust particles are also present all year round, though with some seasonal variability, with intense dust events tending to occur in spring (Prospero et al., 2002; Tulet et al., 2008). Some contribution of secondary organic aerosol from vegetation and nitrates from soil $\mathrm{NO}_{\mathrm{x}}$ is also expected, particularly during the wet season (Delon et al., 2010; Capes et al., 2009). Subsequent to emission, anthropogenic biomass burning particles and natural mineral dust particles become internally mixed to varying degrees. The study of such aerosol mixtures is of particular interest, because their different sizes, chemistries and optical properties may result in significant radiative, climatic and health

Published by Copernicus Publications on behalf of the European Geosciences Union. 
impacts (Kaufman et al., 2002; Lesins et al., 2002; Myhre et al., 2003; Curtis et al., 2006; Solmon et al., 2008; Carmichael et al., 2009; http://www.ipcc.ch/ipccreports/ar4-wg2.htm).

Before the AMMA (Multidisciplinary Analysis of African Monsoon) program (http://www.amma-international.org/), only a few field studies have discussed Western African aerosols and only for selective periods. For example, experimental work on emissions was performed within the DECAFE (Lacaux et al., 1995) and EXPRESSO (Delmas et al., 1999) programs, while studies on deposition have been carried out within the IDAF (IGBP/IGAC/DEBITS in Africa) network (http://www.medias.obs-mip.fr/IDAF; Galy-Lacaux et al., 2009) and a number of studies on aerosol radiative impacts have been performed within the AERONET network (http://aeronet.gsfc.nasa.gov/; Holben et al., 1998). Initial global modeling simulations of biomass burning aerosols associated with experimental work and the development of emission inventories may be found in Liousse et al. (1996) and Liousse et al. (2004). In parallel, dust emission parameterizations (Marticorena and Bergametti, 1995) have been developed and studies have been performed investigating Saharan dust within National and European programs (e.g. the Saharan Dust Experiment, SHADE, Tanré et al., 2003). Initial experimental and modeling work discussing heterogeneous aerosol processes including $\mathrm{HNO} 3$ and dust interactions were conducted e.g. by Galy-Lacaux et al. (2001) and Bauer et al. (2004).

The AMMA program offers a unique opportunity to study Western African aerosols and their impacts, since participants in the project are working together on many different aerosol features, such as emissions, modeling and measurements of both dust and combustion aerosols. Within the program, different observation periods were considered: both long term (AMMA-LOP, Long Observation Period/IDAF, 2005-2010) and short term (EOP, Enhanced Observation Period, 2005-2007) observation periods were combined with intensive campaigns (SOP, Special Observation Period, 2006) (Lebel et al., 2009). Moreover, observations from the AMMA SOP experiments have been further enriched by the DODO and DABEX (Haywood et al., 2008) experiments. Many recent papers pertaining to West African aerosols show new and interesting results obtained from these campaigns (Marticoréna et al., 2010). For example, Haywood et al. (2008) determined the vertical distribution of West African aerosols during the fire season, showing that a dust layer exists at the surface while an elevated smoke layer persists above. New chemically resolved aerosol observations are described in Capes et al. (2009), Léon et al. (2009), Kim et al. (2009), Chou et al. (2008), Johnson et al. (2008), Osborne et al. (2008), Rajot et al. (2008). Heterogeneous processes have been studied by Crumeyrolle et al. (2009) and Matsuki et al. (2010). Myhre et al. (2008) and Pinker et al. (2010) simulate aerosol mixtures of mineral dust and biomass burning aerosol at regional scales and resolutions. Finally radiative and climatic impacts for such aerosols have been investigated by Mallet et al. (2008), Derimian et al. (2008), Raut and Chazette (2008) and Solmon et al. (2008).

Our present work focuses on the development of the AMMA biomass burning emission inventory AMMABB with particular focus on combustion aerosols.

A first challenge was to develop real-time biomass burning emissions for the AMMA EOP period (2005-2007) for gases and particles. Calculating emissions from savannas, forests and agricultural fires requires a knowledge of appropriate emission factors as well as spatial and temporal distributions of burnt biomass. First attempts to quantify burnt biomass on a regional/global scale were based on FAO (United Nations Food and Agriculture Organization) land use statistics complemented with general assumptions about percentages of burnt surfaces per year (Hao et al., 1990; Hao and Liu, 1994; Liousse et al., 1996). Following Hao et al. (1990), it was assumed that $50-75 \%$ of west african savannas burned each year, though with a factor of $2-3$ in uncertainty. The first qualitative improvements in fire temporal evolution were achieved with the use of active fire satellite products (Cooke et al., 1996). Later, burned area products were used to improve quantitative estimates (Liousse et al., 2004) particularly over Africa where such products have been validated (Tansey et al. 2004; Jain et al., 2008; Stropppiana et al., 2010). Inventories have since been developed using either active fire, burned area products or both (Chin et al., 2002, Ito and Penner, 2004; Hoelzemann et al., 2004, Liousse et al., 2004; Michel et al., 2005; Van der Werf et al., 2006, Generoso et al., 2007), an approach which appears to reduce uncertainties (Michel et al., 2005 and Stroppiana et al., 2010). Very recently, determination of satellite fire radiative energy has been seen to be directly correlated with fire emissions and allowing the development of new inventories (still in validation) without vegetation parameterization and consequently with reduced uncertainty (Wooster et al., 2002, 2005; Ichoku and Kaufman 2005). In our work, presented in Sect. 2, SPOT-VGT satellite products were used to develop emission inventories following the methods of previous studies performed over Africa, using the AVHRR burned area products for 1980-1989 (Liousse et al., 2004) and the SPOT GBA 2000 products for the year 2000 (Mieville et al., 2010 and Konare et al., 2010).

A second challenge was to verify the use of these new biomass burning emissions in global/regional transport models, with comparisons with surface, satellite and column integrated measurements obtained during the AMMA experiment. In this paper, we use the global ORISAM-TM4 chemistry-transport model, which is specially adapted to our needs. ORISAM-TM4 does not separately consider different aerosol components, and AOD values are thus not calculated by adding the effects of all components as, for example in Kinne et al. (2006) or Koch et al. (2009). The new code used in the present study, ORISAM-RAD, includes the calculation of time-evolving aerosol size distributions 
Table 1. Correspondence between BDv, BEv and $\mathrm{EF}(\mathrm{BC})$ in each GLC vegetation class.

\begin{tabular}{lccc}
\hline GLC map & Biomass Density (BD. kg/m $\left.{ }^{2}\right)$ & Burning efficiency (BE) & EFBC (g/kg) \\
\hline Broadleaf evergreen GLC1 & 23.35 & 0.25 & 0.7 \\
Closed broadleaf deciduous GLC2 & 20 & 0.25 & 0.6 \\
Open Broadleaf deciduous GLC3 & 3.3 & 0.4 & 0.62 \\
Evergreen needleleaf forest GLC4 & 36.7 & 0.25 & 0.6 \\
Deciduous needleleaf GLC5 & 18.9 & 0.25 & 0.6 \\
Mixed leaf type GLC6 & 14 & 0.25 & 0.6 \\
Mosaic: tree cover/other natural vegetation GLC9 & 10 & 0.35 & 0.61 \\
Shrub. closed-open, evergreen GLC11 & 1.25 & 0.9 & 0.62 \\
Shrub. closed-open, deciduous GLC12 & 3.3 & 0.4 & 0.62 \\
Herbaceous cover, closed open GLC13 & 1.425 & 0.9 & 0.62 \\
Sparse herbaceous or sparse shrub cover GLC14 & 0.9 & 0.6 & 0.67 \\
Cultivated and managed areas GLC16 & 0.44 & 0.6 & 0.725 \\
Mosaic: cropland/tree cover/other natural vegetation GLC17 & 1.1 & 0.8 & 0.64 \\
Mosaic: cropland/shrub or grass GLC18 & 1 & 0.75 & 0.65 \\
\hline
\end{tabular}

in six bin sizes between $0.04 \mu \mathrm{m}$ to $40 \mu \mathrm{m}$. A detailed aerosol chemistry module is coupled with an atmospheric gas scheme, through thermodynamical equilibria between gas and liquid phase for inorganic components (sulfate, nitrate, ammonium), whilst an empirical approach based on grouping VOCs with similar volatilities and chemical properties is used for secondary organic aerosol (Odum et al., 1996). Major primary aerosols are black carbon (BC), organic carbon (OC), dust and sea salt, dissociated into chlorine and sodium ions. Water is included as a reactive component in online optical properties calculations, as for all other components. Ensuing optical properties (extinction, scattering and absorption) are then calculated assuming internally core/shell mixed aerosols (Mallet et al., 2005, 2006; Péré et al., 2009). These approaches are similar to Jacobson (2001), Ghan et al. (2001), Stier et al. (2005) and Bauer et al. (2010). A global simulation was performed, covering the EOP period, using the ORISAM-RAD code implemented in the TM4 global chemistry-transport model. Our study also took advantage of the very recent seasonal AMMA aerosol measurements. Of special interest were the AMMA LOP (with IDAF and AERONET programs) and EOP periods, which were more coherent with the global model spatial and temporal resolutions. Particular focus was made on savanna sites highly impacted by biomass burning, especially at the new Djougou (Benin) site (Serça et al., 2007, Galy et al. 2007, Pont et al., 2009). A description of the model and comparison between simulation results and measurements is displayed in Sect. 3.

\section{Biomass burning emissions}

\subsection{Methodology}

Daily, open global biomass burning emissions for gases $\left(\mathrm{CO}_{2}, \mathrm{CO}, \mathrm{NO}_{\mathrm{x}}, \mathrm{SO}_{2}\right.$ and $\left.\mathrm{VOC}\right)$ as well as black carbon (BC) and organic carbon (OC) particles were estimated for the AMMA campaign period (2000-2007), at a horizontal resolution of $1 \mathrm{~km} \times 1 \mathrm{~km}$ over Africa, using a bottom-up approach. The following relationship was considered:

$\mathrm{EM}=\Sigma \mathrm{v}(\mathrm{BA} \times \mathrm{GLCv} \times \mathrm{BDv} \times \mathrm{BEv} \times \mathrm{EFv})$.

where $\mathrm{EM}$ is the total emission estimate and $\mathrm{BA}$ the Burnt Area described by the L3JRC product for the period 2000-2007 (Tansey et al., 2008) at a spatial resolution of $1 \mathrm{~km} \times 1 \mathrm{~km}$, and at daily temporal resolution. These data are derived from the Spot-Vegetation satellite. GLCv represents the percentage of each class of vegetation $\mathrm{v}$ present within each cell of the $0.5^{\circ} \times 0.5^{\circ}$ vegetation map. The GLC vegetation map (Global Land Cover, developed at JRC-Ispra (http://ies.jrc.ec.europa.eu/global-land-cover-2000) is used, since optimized for studies in Africa for the year 2000. Account is made of 21 different classes of vegetation from which 14 can support fire events.

$\mathrm{BDv}$ and $\mathrm{BEv}$ are, respectively, the biomass densities (biomass per unit area occupied by a vegetation type in $\mathrm{kg} / \mathrm{m}^{2}$ ), and burning efficiencies (fraction of biomass exposed to fire and actually consumed in fire) for each vegetation class, v. An important work performed in the frame of the AMMA and GICC (Gestion et impacts du changement climatique, www.gip-ecofor.org/gicc/) programs was to derive the values of $\mathrm{BDv}, \mathrm{BEv}$ for each GLC vegetation class (see also Mieville et al., 2010). The description of each different GLC class is given in Table 1. This study is based on 
inputs from Mayaux (Mayaux, 2007) as well as from Michel et al. (2005) and Konaré et al. (2010). EFv is the emission factor (given in $\mathrm{g} / \mathrm{kg}$ of dry matter) for the particular gaseous or particulate species considered, and depends on the vegetation class. EF values for black carbon and organic carbon are taken from Liousse et al., (2004). Other EF values for gaseous species $\left(\mathrm{CO}_{2}, \mathrm{NO}_{\mathrm{x}}, \mathrm{VOCs}, \mathrm{SO}_{2} \ldots\right)$ were selected following Andreae and Merlet, (2001). Table 1 resumes all values used for BDv, BEv and EFv for black carbon particles.

It should be noted that a detailed comparison performed for the year 2000 between the L3JRC and Landsat satellite burned area products with a $30 \mathrm{~m} \times 30 \mathrm{~m}$ spatial resolution (http://geo.arc.nasa.gov/sge/landsat/17.html) revealed systematic underestimation of burned areas in the L3JRC product as compared to Landsat data for the GLC3 and GLC12 vegetation classes. Consequently, corrections were applied in this study, using values obtained from this comparison. Burnt areas for the GLC3 and GLC12 vegetation classes, typical of west African ecosystems, were increased by factors of 2 and 1.67, respectively (JRC report September 2007, Grégoire, 2007). This specific version of the inventory is called L3JRcor in the following section.

Relative uncertainties linked to AMMABB emissions inventories ( $\mathrm{uEM}$ ), of the order of $57 \%$, are obtained using the following calculation:

$\mathrm{uEM}=\left(\mathrm{uBA}^{2}+\mathrm{uGLC}^{2}+\mathrm{uBD}^{2}+\mathrm{uBE}^{2}+\mathrm{uEF}^{2}\right)^{1 / 2}$

where $\mathrm{uBA}$ is the relative uncertainty of burnt areas : uBA = 0.20 (Tansey et al. 2008), uGLC, the relative uncertainty of percentage of vegetation class per cell : uGLC $=0.20$ (Stroppiana et al., 2010; Jain et al., 2007),

uBD the relative uncertainty of biomass density : $\mathrm{uBD}=0.30$ (Stroppiana et al., 2010; Jain et al., 2008), uBE the relative uncertainty of burning efficiencies : $\mathrm{uBE}=0.25$ (Stroppiana et al., 2010; Jain et al., 2008) and uEF the relative uncertainty of emission factors : $\mathrm{uEF}=0.31$ (Andreae et Merlet 2001).

\subsection{Results}

Figure 1 shows total emissions of black carbon particles from African biomass burning for December 2005 through February 2006 and June through August 2006. BC emissions are maximum in December in the northern hemisphere while they peak in July in the southern hemisphere. Minimum BC emissions occur in March, April and May, despite persistent fires in North-East and Southern Africa (not shown here). In the Northern hemisphere, maximum BC emissions are located in Central Africa, although some hot spots can be found in West Africa, with higher local intensities in 2005 than in 2006. The contrary is indicated at the regional scale, with higher BC emissions in 2006 than in 2005, as shown in Fig. 2a, which displays the interannual variability of African BC emissions averaged for December, January and February (DJF) from 2000 to 2007. Interestingly, BC emissions

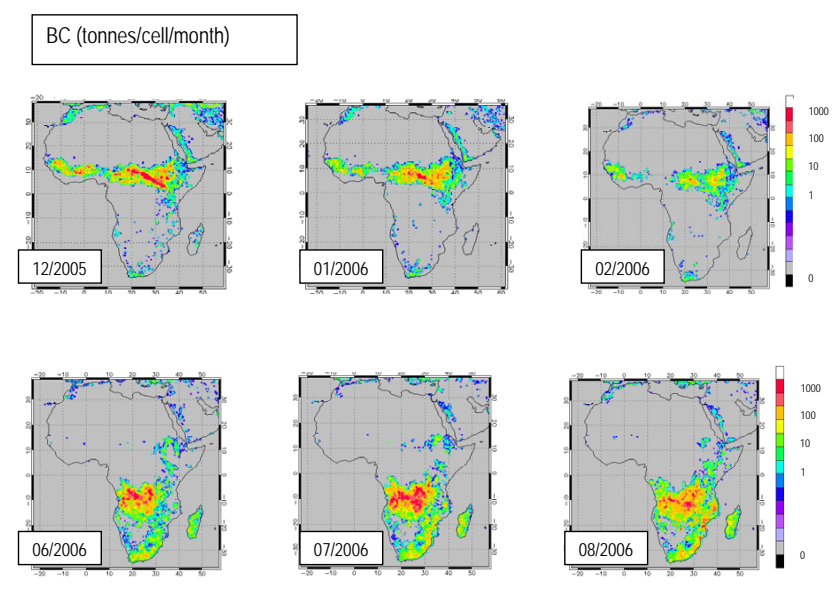

Fig. 1. Spatial distributions of BC emissions from December 2005 through February 2006 and June through August 2006 with the new AMMABB inventory (at $0.5^{\circ} \times 0.5^{\circ}$ resolution).
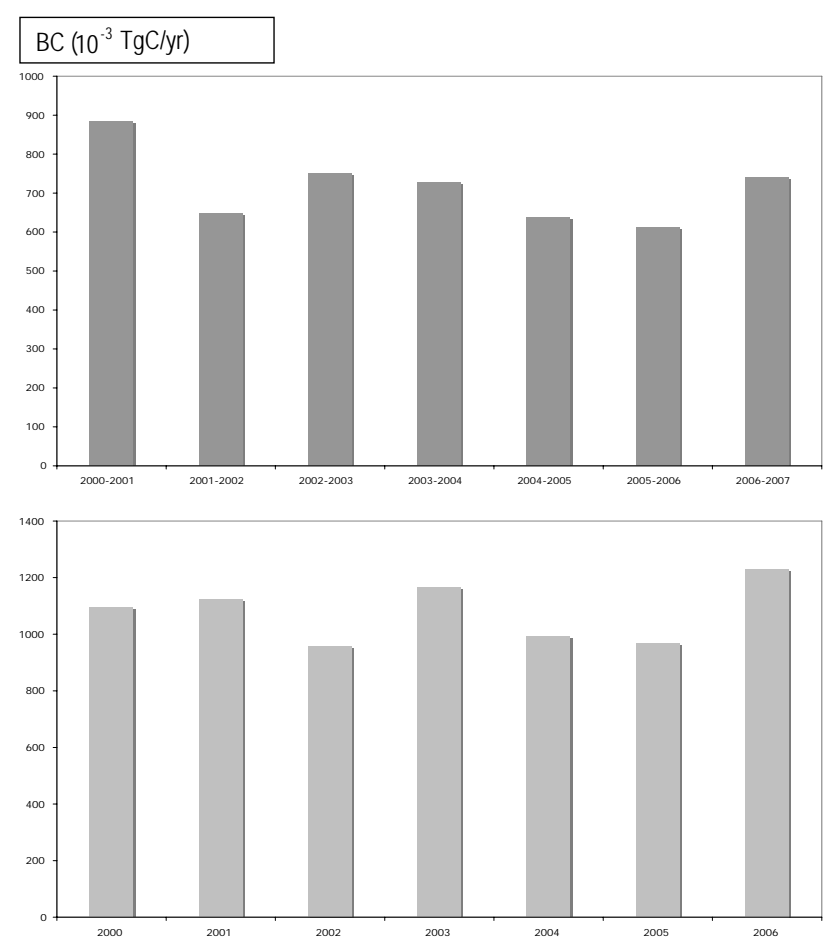

Fig. 2. African biomass burning $B C$ emissions $\left(10^{-3} \mathrm{TgC} / \mathrm{yr}\right)$ from 2000 to 2007 for (a) December, January and February and (b) June, July and August.

for this period range roughly from 0.6 to $0.9 \mathrm{TgC} / \mathrm{yr}$ (a $30 \%$ variation).

Maximum BC emissions $(\sim 0.9 \mathrm{TgC} / \mathrm{yr})$ occur in 2000 2001 , whereas minimum emissions $(\sim 0.6 \mathrm{TgC} / \mathrm{yr})$ are indicated in 2005-2006. Figure $2 \mathrm{~b}$ displays interannual variability of annual African BC emissions for June, July, August (JJA) from 2000 to 2006. These interannual variations are 
Table 2. Yearly (2006) biomass burning emission budgets for BC and OC in Africa and West and Central Africa as given by this inventory and by GFED 2 inventory (Van der Werf et al., 2006, 2008) http://www.ess.uci.edu/ jranders/.

\begin{tabular}{lllll}
\hline Tg species/yr & $\begin{array}{l}\text { Africa } \\
\text { (AMMABB) }\end{array}$ & $\begin{array}{l}\text { Africa } \\
\text { (GFED 2) }\end{array}$ & $\begin{array}{l}\text { W. and C. Africa } \\
\text { (AMMABB) }\end{array}$ & $\begin{array}{l}\text { W. and C. Africa } \\
\text { (GFED 2) }\end{array}$ \\
\hline $\mathrm{BC}(\operatorname{TgC})$ & 2.3 & 0.95 & 0.5 & 0.25 \\
$\mathrm{OCp}(\operatorname{TgC})$ & 17 & 7 & 3.3 & 1.8 \\
\hline
\end{tabular}

mainly related to Southern hemisphere fire activity (Fig. 1). It is interesting to note that in the L3JRCcor inventory, BC emission levels are slightly higher in the southern hemisphere. Interannual variations are slightly smaller in the JJA season as compared to the DJF period, with maximum variability in a $25 \%$ range of. Maximum $\mathrm{BC}$ emissions occur in JJA 2006 (with $1.2 \mathrm{TgC} / \mathrm{yr}$ ), while for DJF maximum emissions occur in 2000-2001. Minimum BC emissions occur in 2005 for both the JJA $(0.95 \mathrm{TgC} / \mathrm{yr})$ and DJF seasons. Among different possible causes, these interannual variations may be related to ENSO/ La Nina episodes.

Table 2 summarizes annual African and West/Central Africa BC and OC biomass burning emissions for the year 2006. Data from the GFED2 inventory (Van der Werf et al., 2006, 2008) have been included for comparison. In both cases (total Africa or West and Central Africa), we note that AMMABB estimates are higher than GFED2. This feature was also noted shown in Tummon et al. (2010) and Barret et al. (2010). In order to better understand such differences, a joint international effort aimed at improved identification of uncertainties in existing biomass burning inventories has been organized. The global inter-comparison exercise INTERMEDE BBSO (see the ACCENT European Network website, http://www.accent-network.org) aimed to analyze $\mathrm{CO}$ emissions derived from different satellite products in order to further investigate these uncertainties (Stroppiana et al., 2010). The best agreement was found for CO emissions over the African continent, with a maximum difference of about $45 \%$ between products for the year 2003. Figure 3 presents monthly CO budget results for Africa for 2003, as derived by a number of published inventories. The same vegetation parameterization and emissions factors were used by Mieville et al., 2010, Chin et al., 2002 and in this work; however different burnt biomass distributions were obtained from ATSR active fires scaled with GBA 2000 burnt areas, MODIS active fires and L3JRC burnt areas, respectively. A dynamical vegetation model was used in combination with the MODIS active fire product to produce the GFED2 inventory, whilst the dynamical vegetation model was combined with both the MODIS active fire and burnt area products to generate the GFED3 inventory. Pétron et al. (2004) used a top-down approach from MOPITT CO concentrations. As already mentioned, the GFED2 and GFED3 inventories provide the lowest estimates throughout the year. L3JRCcor

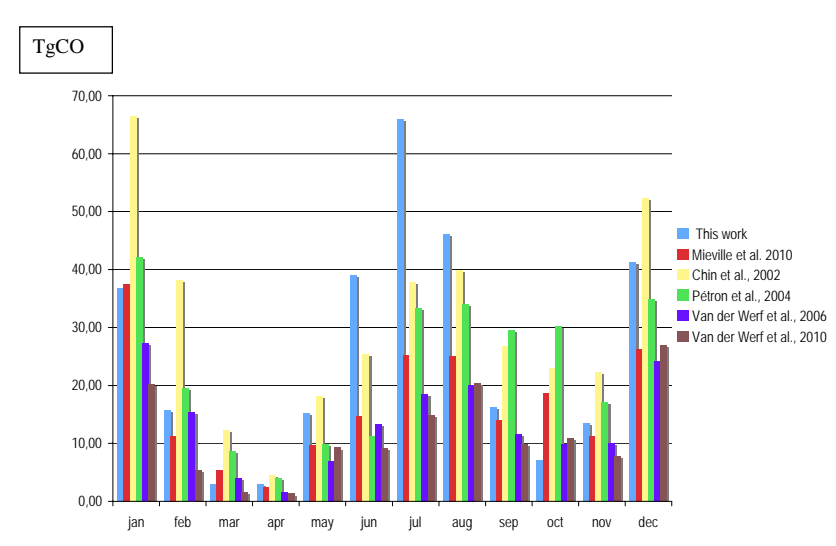

Fig. 3. Monthly CO budget for different emission inventories in Africa (year 2003).

(this work) is higher than all other inventories during the JJA season due to significant burning in the savanna/grassland biomes. The Chin et al. (2002) inventory is higher in winter as a result of considerable burning in the agricultural sector. Further details of this comparison can be found in Stroppiana et al. (2010).

\section{Evaluation of AMMABB emission inventories through comparison of model results and atmospheric observations}

The AMMABB inventory for combustion aerosols has been evaluated using the global ORISAM-TM4 chemistrytransport model. For this purpose, simulation results using the emissions inventory described in the previous section were compared with the recent AMMA measurements.

\subsection{Model description}

The ORISAM-TM4 model (Guillaume et al., 2007) is based on the coarse resolution TM4 model (http://www. knmi.nl/ velthove/tm.html), a global Chemistry-Transport Model, developed at KNMI (Royal Netherlands Meteorological Institute). The model has a horizontal resolution of $3^{\circ} \times 2^{\circ}$ in longitude and latitude, and 31 vertical levels extending from the surface to $40 \mathrm{hPa}$ (Dentener and Crutzen, 
1994; Van Velthoven and Kelder, 1996; Houweling et al., 1998). A version with 9 vertical levels is coupled with the ORISAM model, an aerosol model developed at the Laboratoire d'Aérologie (Liousse et al., 2005; Bessagnet et al., 2009). This latter model takes into account the chemistry of ozone and its precursors (Houweling et al., 1998), as well as the chemical formation of secondary organic and inorganic aerosols (sulfate, nitrate, ammonium, and water) from condensation of gaseous precursors onto primary particles (BC, primary $\mathrm{OC}$, dust). Size and microphysical aging are also taken into consideration. Sea-salt (chlorine and sodium) particles are included. Thirty-eight gaseous compounds are involved in ozone chemistry and secondary aerosol formation. Gas particle partitioning for inorganic species is solved using ISORROPIA (Nenes et al., 1998) while empirical coefficients (Kp) used for organic species (Odum et al., 1996).

In the present work, 6 classes of aerosol diameters are included (size bins from $0.04 \mu \mathrm{m}$ to $40 \mu \mathrm{m}$ ), together with nucleation (Kulmala et al., 1998), coagulation and condensation processes (Gelbard et al., 1980). Dust and sea-salt emissions are produced following the parameterizations of Zakey et al. (2006) and Gong et al. (2003). Aqueous chemistry for sulfate particles in cloud droplets follows the work of Dentener and Crutzen, (1994). Heterogeneous reactions on sea-salt are included, following Nenes et al. (1998) whereas coarse nitrate formation on dust follows Bauer et al. (2004) and Hodzic et al. (2006). Finally, $\mathrm{H}_{2}, \mathrm{NO}_{2}, \mathrm{~N}_{2} \mathrm{O}_{5}$, and $\mathrm{NO}_{3}$ heterogeneous chemistry is based on Jacob (2000).

Aerosol optical properties are calculated with the RADiative (RAD) model (Mallet et al., 2005, 2006) applied to ORISAM-TM4 results, assuming a 3-layer internally mixed aerosol structure. The particle core is assumed made of BC and dust, with a first shell of primary organic carbon and the second one of sea salt and secondary aerosol species (SOA, sulfates, nitrates).

Biomass burning emissions for gases and particles are taken from the AMMABB inventory, as described in Sect. 2. These emissions also account for fire injection heights and different vertical distributions are introduced in the model for savanna and forest burning following Lavoué et al. (2000). The emissions from other natural processes and those resulting from anthropogenic activities are described in Guillaume et al. (2007). Natural emissions of oceanic DMS, volcanic sulfur and soil NOx are taken from the GEIA emissions portal (http://www.geiacenter.org/), while NOx produced by lightning and organic biogenic precursors (terpenes) are taken from the POET inventory (Granier et al., 2005). Anthropogenic black and organic carbon emissions from fossil and bio-fuels are adapted from Junker et Liousse (2008) for the year 2003 (Assamoi and Liousse, 2010). Anthropogenic emissions of gaseous compounds ( $\mathrm{SO} 2$, NOx, NH3) are extracted from the EDGAR3.2 inventory for the year 1995 (Olivier et al., 1999, http://www.mnp.nl/edgar/ model/v32ft2000edgar/), except for CO and VOCs, from the POET inventory (Granier et al., 2005), and NOx aviation emissions taken from the ANCAT 1998 database (Gardner et al., 1997). Primary sulfate emissions are assumed to be $2.5 \%$ of $\mathrm{SO}_{2}$ emissions. The selected anthropogenic emissions appeared to be the most suitable dataset available for this study. Recent developments, for example by Assamoi and Liousse (2010), will improve the available choice of inventories, with an expected increase of emissions in West African megapoles in this inventory.

Emissions of carbonaceous aerosols appear in two modes in the sectional model. The first mode has a mass diameter of $0.23 \mu \mathrm{m}$ while the second mode (only including $20 \%$ of OC emissions) has a mass diameter of $2.5 \mu \mathrm{m}$ (Cousin et al., 2005). BC and OC emissions are partitioned into hydrophobic and hydrophilic fractions. For both species, the transition from hydrophobic to hydrophilic types through absorption, condensation and coagulation is parameterized using a simple constant turnover time (Cooke et al., 1999), since no global consensus exists as for ageing and hygroscopicity of carbonaceous aerosol. Secondary organic aerosols were considered fully hygroscopic. Wet and dry deposition parameterizations are described in Guillaume et al. (2007). In particular, wet deposition, apart from including in-cloud and below cloud scavenging also accounts for $\mathrm{SO}_{2}$ oxidation within cloud droplets and rain drops.

A global simulation was performed with the ORISAMRAD-TM4 model for the entire AMMA campaign, including the EOP (Enhanced Observation Period), from December 2004 to March 2007, with a spin up period of one month. The model was forced with ERA 40 (ECMWF) wind and precipitation fields, updated every $6 \mathrm{~h}$.

\subsection{Results}

\subsubsection{Black carbon surface concentrations}

Comparisons between modeled and observed BC surface concentrations at AMMA/IDAF super-sites (see the map in Fig. 4a) are presented for Banizoumbou (Niger) from December 2004 to November 2005 (Fig. 4a), Lamto (Ivory Coast) from May 2006 to October 2006 (Fig. 4b) and Djougou (Benin) from June 2005 to March 2007 (Fig. 5a). Observed BC concentrations at Djougou and Banizoumbou were measured using a seven-wavelength aethalometer. The absorption coefficients which were measured by aethalometers at the AMMA super-sites were influenced not only by highly absorbing combustion aerosols, but also by dust particles containing various absorbing fractions (Alfaro et al., 2004). In order to take this into consideration, we applied the methodology of Fialho et al. (2005) to the measured absorption signal at Djougou and Banizoumbou to correct for dust interaction. Absorption values were thus decreased on the order of $9-13 \%$. No correction is applied to the data obtained from Lamto, where BC values were obtained using a single-wavelength aethalometer. 


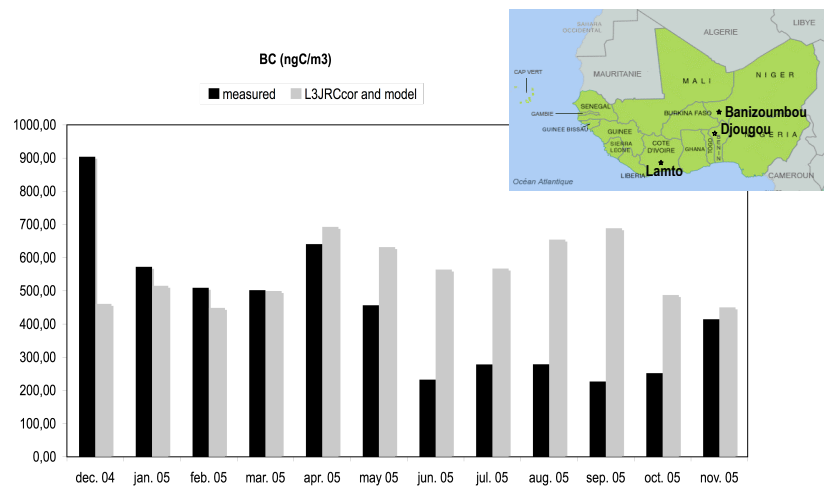

(a)

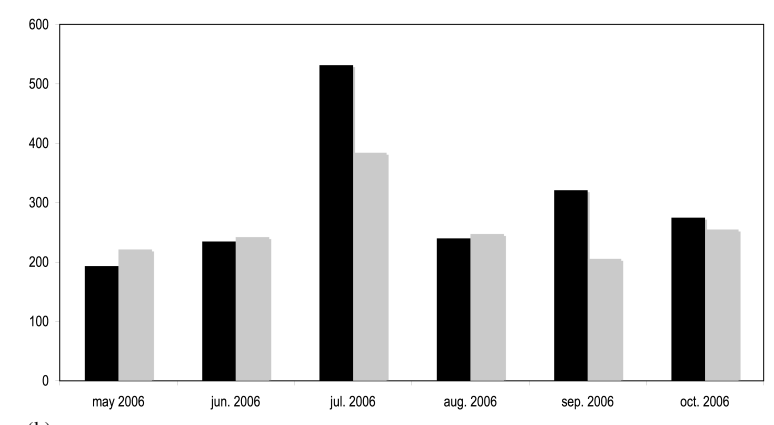

(b)

Fig. 4. Measured (IDAF/AMMA-LOP) and modeled (ORISAMTM4) BC concentrations at (a) Banizoumbou (Niger) and (b)Lamto (Ivory Coast).

Many previous studies have further suggested that aethalometer measurements need to be corrected for multiple scattering by the filter fibers, scattering of aerosols embedded in filters and filter loading artifact (Liousse et al., 1993; Petzold et al., 1997; Bond et al., 1999). Collaud Coen et al. (2010) have summarized the different corrections (respectively the "Weingartner", the "Arnott", the "Schmid", the "Virkkula" corrections) with new correction algorithms and recommendations. Most of the corrections require parallel aethalometer and scattering measurements. In our case, without such measurements and following Collaud Coen et al. (2010), the corrections at a biomass burning site would be a $23 \%$ reduction of absorbing coefficients (and thus of $\mathrm{BC}$ concentrations). Finally, even though the relative uncertainty regarding measured $\mathrm{BC}$ concentrations was first given to be on the order of $10 \%$ (Hansen et al., 1982), an uncertainty of $30 \%$ on aethalometer $\mathrm{BC}$ measurements has been retained in this study.

Mean BC concentrations as well as seasonal variability of $\mathrm{BC}$ concentrations are generally well reproduced by the model. At Banizoumbou, the model presents higher BC concentrations than observed during the wet season. This is possibly due to uncertainties in the parameterization of $\mathrm{BC}$ wet deposition in the model or as a result of errors in simulated precipitation. At Lamto (Fig. 4b) the model gives lower con-
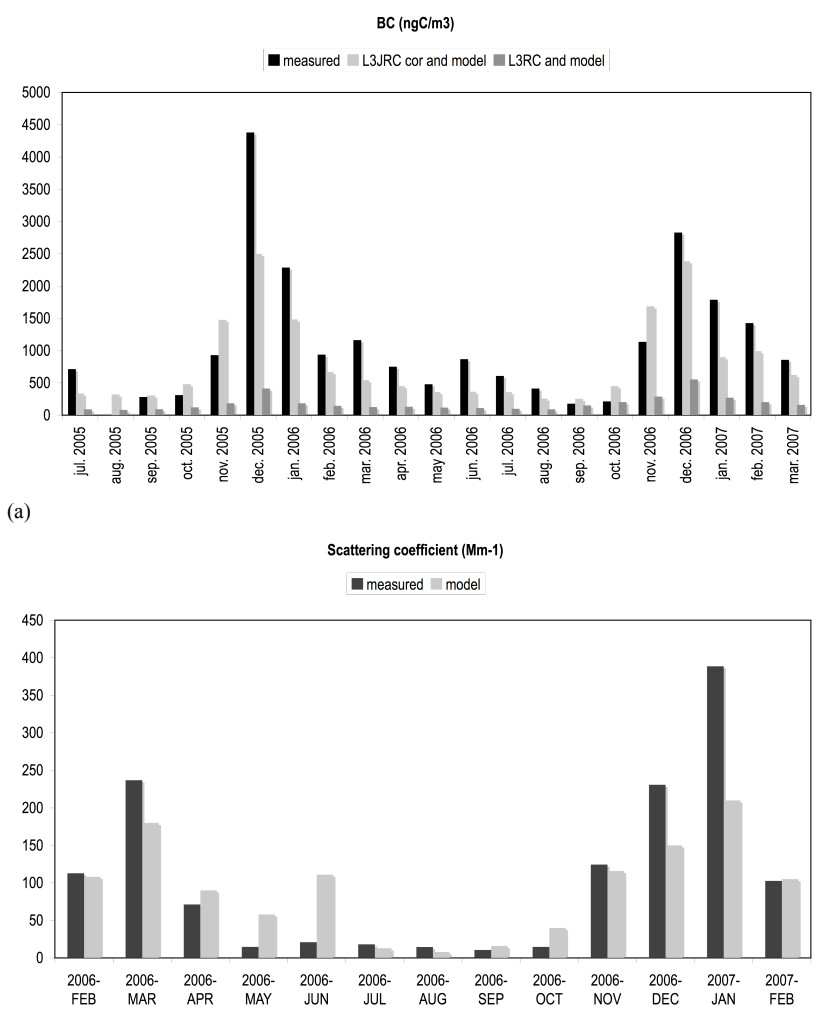

(b)

Fig. 5. Measured (AMMA-EOP, AERONET) and modeled (ORISAM-TM4) with different biomass burning sources) (a) BC concentrations and (b) scattering coefficients at $520 \mathrm{~nm}$ at Djougou (Benin)

centrations than observations in July 2006. Again, this may possibly be explained by excessive aerosol removal due to overestimated precipitation, a known error in the ERA-40 reanalysis in the Guinean Gulf region (Uppala et al., 2005). Despite relatively good agreement between model and observations at Djougou, modeled values using the L3JRCcor inventory are lower by $40-50 \%$ than observations in December 2005. Coarse horizontal and vertical grid resolution model at a specific site may explain such differences with observations. Moreover, as shown earlier, experimental data issued from aethalometer analyses, may be overestimated by up to $23 \%$. Discrepancies between model and measurements would be reduced if such correction was applied. In Fig. 5a, modeled results are also given at Djougou for L3JRC inventory without the L3JRC satellite data correction (see Sect. 2). It is interesting to note that this inventory has a very large impact on modeled BC concentrations (with a modeled BC concentration decreasing by a factor of 6), thus emphasizing the importance of the choice of biomass burning inventory and, in this case, of the corrected version of the inventory. In summary, the model associated with the AMMABB biomass burning inventory satisfactorily reproduces the interannual $\mathrm{BC}$ variability, with both observed and modeled 
$\mathrm{BC}$ concentrations being slightly higher during the 2005 dry season than in the 2006 dry season, in agreement with local biomass burning emissions (see Sect. 2).

\subsubsection{Djougou aerosol optical properties}

This section deals with the comparison between modeled and measured aerosol optical properties at Djougou. Scattering coefficients were measured from February 2006 to February 2007 with a single-wavelength $(0.52 \mu \mathrm{m})$ ECOTECH nephelometer, with 10\% error (Formenti et al., 2002) (Fig. 5b). Aerosol optical depth (AOD) and column-integrated single scattering albedo (SSA) are retrieved at $441 \mathrm{~nm}$ from January 2005 to March 2007 from direct sunphotometer and almucantar measurements (Dubovik et al., 2000) (error about \pm 0.01 (Holben et al., 1998) and \pm 0.03 (Dubovik et al., 2000), for AOD (Fig. 6a) and SSA (Fig. 6b), respectively). Experimental methods used to obtain these observations are described in Mallet et al. (2008). It should be noted that variations in such parameters as AOD, SSA, scattering coefficient include the impacts of both dust and combustion aerosol. As for BC comparisons, both mean values and seasonal variability of the simulated scattering coefficient are generally well captured by the model.

Two main discrepancies between the model and observations can be observed. First, in June, the modeled scattering coefficients are higher than observations. Since this difference does not appear in the simulated $\mathrm{BC}$ concentrations (see Fig. 5a), this is likely mainly due to uncertainties in other aerosol components, such as dust concentrations. Interestingly, the March 2006 dust event described by Tulet et al. (2008) and Mallet et al. (2009) is well captured by the model. A second problem occurs in January 2007, when modeled scattering coefficients are lower than observations. This issue was already noted regarding BC concentrations, and can possibly be explained by the fact that local biomass burning sources may not be adequately taken into account in the coarse resolution model.

AOD comparisons are shown in Fig. 6a, for both coarse (AODc) and fine particles (AODf) at $441 \mathrm{~nm}$. Reasonable comparison is found for fine particles, with modeled values slightly lower than observations (on the order of $41 \%$ ), except for May and June 2006 when modeled values are approximately $18 \%$ higher than experimental ones. This is consistent with the previous comparisons for both BC and scattering coefficients (see Fig. 5a and b). The comparison is quite different for coarse AOD. From January 2005 to June 2006, modeled values are higher than observations (the difference ranging from $14 \%$ to $315 \%$ ), whereas they are lower from August 2006 to March 2007 (the difference ranging from $0.1 \%$ to $56 \%$ ). These differences are much more significant outside the main fire season, possibly due to uncertainties in the dust scheme.
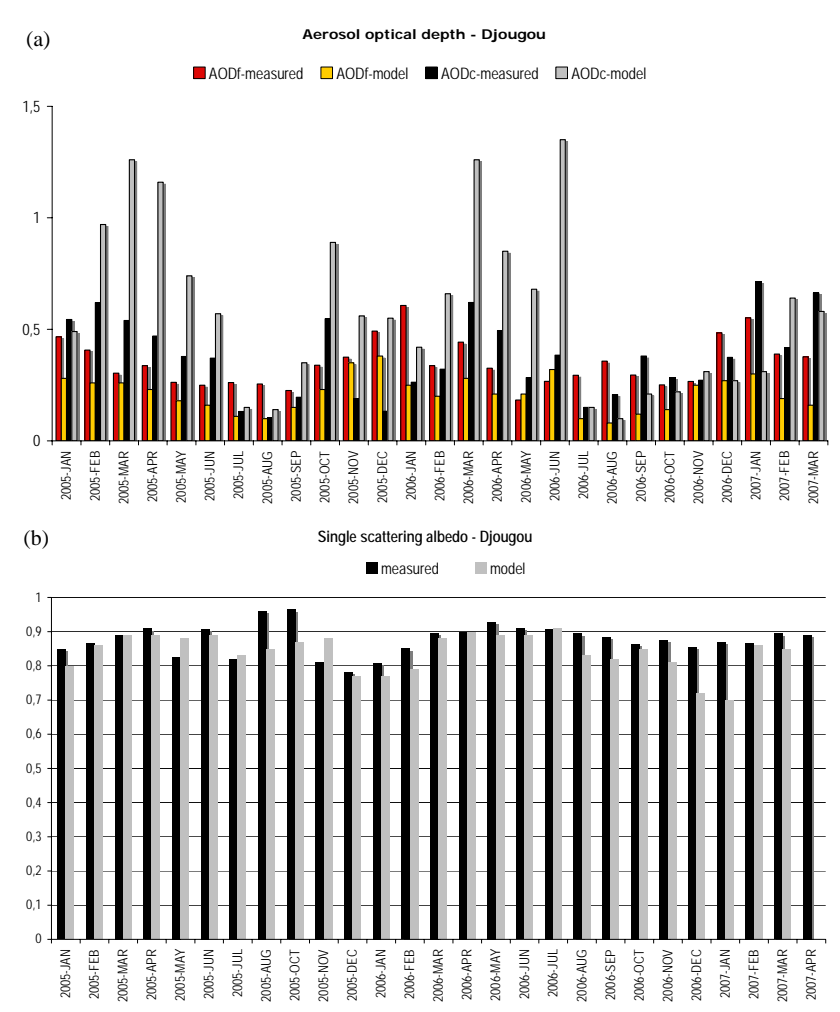

Fig. 6. Measured (AMMA-EOP, AERONET) and modeled (ORISAM-TM4) (a) aerosol optical depths for coarse and fine particles and (b) single scattering albedos at Djougou (Benin) at $441 \mathrm{~nm}$.

Finally, Fig. 6b shows a comparison between modeled and measured single scattering albedo (SSA). Mean SSA values, as well as seasonal variations are well captured by the model. However, the differences mentioned in Figs. 5a, b and 6a for December 2006 and January 2007 (underestimates of both simulated scattering coefficient and AOD) result in lower modeled SSA values (i.e. more absorption) than observed. It is also possible that the $100 \%$ core/shell mixing treatment applied in the ORISAM-RAD model tends to overestimate aerosol absorption as observed by Péré et al., (2010). Indeed, increase of water uptake in case of high hydrophilic aerosol concentrations may reinforce light refraction from the aerosol shell into the aerosol BC core, thus enhancing particle absorption (Moffet and Prather, 2009). It is thus possible that a combination of externally- and internally-mixed particles could be more realistic in the African domain.

Similar general agreement is also found at Banizoumbou (Niger), particularly for fine particles, though comparisons between observations and model are more complex than at Djougou. Figure 7a displays AOD comparisons at $441 \mathrm{~nm}$, respectively for both coarse (AODc) and fine particles (AOCf). Outside the fire season, model values are higher than observed ones whereas the reverse is true during the fire season, with differences on the order of $35 \%$. This is similar to the trend already observed for BC concentrations 

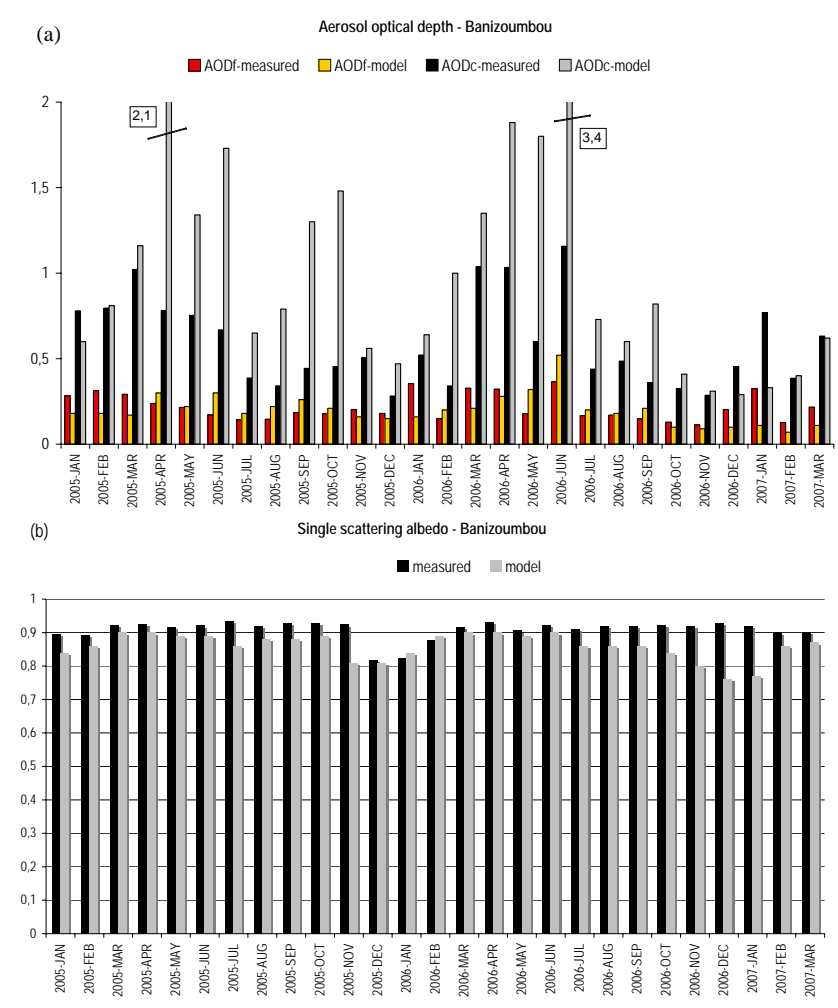

Fig. 7. Measured (AMMA-EOP, AERONET) and modeled (ORISAM-TM4) (a) aerosol optical depths for coarse and fine particles and (b) single scattering albedos at Banizoumbou (Niger) at $441 \mathrm{~nm}$.

in figure 4a. A possible explanation for the wet season can be tentatively found in aerosol deposition and transport whereas in winter, the difference is rather explained considering the ORISAM-TM4 dust scheme. As for AODc, they behave rather similarly to Djougou, model/observation differences being much higher than for AODf with higher modeled values from March 2005 to October 2006 and lower modeled values from November 2006 to March 2007. Finally figure $7 \mathrm{~b}$ displays modeled and observed SSA values at Banizoumbou, very similar to the ones found in Djougou (Fig. 6b). Reasonable comparisons may be found except for the november 2006 to January 2007 period when modeled values are below observations. Such differences could be due to underestimations of modeled coarse particles, again revealing a possible flaw in the dust scheme.

\subsubsection{Vertical distribution of the extinction coefficient at Djougou}

Several previous studies have investigated vertical aerosol profiles in the West African region during the AMMA dry season (the DABEX experiment). Surface lidar and aircraft observations have clearly shown that during the dry season smoke aerosols are located above a dust-rich surface layer
(Osborne et al., 2008; Haywood et al., 2008; Pelon et al., 2008; Leon et al., 2009). Johnson et al (2008) also demonstrated that these relative profiles (a smoke-rich aerosol layer overlying a dust-rich aerosol layer) are adequately represented by the Met Office Hadley Centre HadGEM2 climate model. However they found that the biomass burning smoke was underestimated by a factor of about 2.4 for January 2006 when using GFED1 emission data, which differs little from GFED2 data in northern Africa. Thus, the use of the AMMABB emission data set where emissions are a factor of $\sim 1.8$ larger could help reduce the discrepancy between the model and observations (Table 2).

In our work, as a result of the low vertical resolution of ORISAM-TM4, it is very difficult to capture the complex vertical profile of aerosols that is observed over West Africa. However, in order to further investigate this aspect we conducted several tests focused on the ability of the ORISAMRAD-TM4 model to accurately reproduce aerosol vertical profiles, particularly the aged smoke layer and its vertical distribution. In this regards, we used micropulse Lidar (MPL) observations (Pelon et al., 2008) at Djougou (Northern Benin) at $0.523 \mu \mathrm{m}$ for two specific events, one occurring in January 2006, representative of mixed aerosols, and a second one in March of the same year, when mineral dust particles are predominant.

Figure 8a displays vertical profiles of aerosol extinction coefficients (in $\mathrm{km}^{-1}$ ) as estimated by the MPL and as calculated in the model. For January 2006, the MPL observations clearly indicate the presence of two distinct aerosol layers, one located between the surface and approximately $1.5 \mathrm{~km}$ and a second one located above including smoke aerosols. In this case, ORISAM-RAD-TM4 presents lower extinction coefficient values than observations over the entire profile, but does appear to capture the presence of the second layer $(1.5-$ $4 \mathrm{~km}$ ) with values around $0.07 \mathrm{~km}^{-1}$ at $1.8 \mathrm{~km}$ and $0.03 \mathrm{~km}^{-1}$ at $3 \mathrm{~km}$.

For the March 2006 case of pure mineral dust (Fig. 8b), the model similarly gives lower extinction coefficient values than observations, with a significant underestimation within the dust layer. Indeed, maximum simulated extinction coefficients are approximately $0.25 \mathrm{~km}^{-1}$, while lidar observations suggest values closer to $1.4 \mathrm{~km}^{-1}$. It is, however, interesting to note that the vertical position of the first layer given by the model and the MPL observations are in agreement. In January, this layer most likely mixing dust and fresh biomass burning aerosols appears between 0 and $1 \mathrm{~km}$ whereas in march, this layer is located near $1-1.5 \mathrm{~km}$. At this point, however, it is difficult to isolate one particular source of error, and any one or a combination of factors such as the model vertical or horizontal resolution, model dynamics or dust production scheme could be involved. 

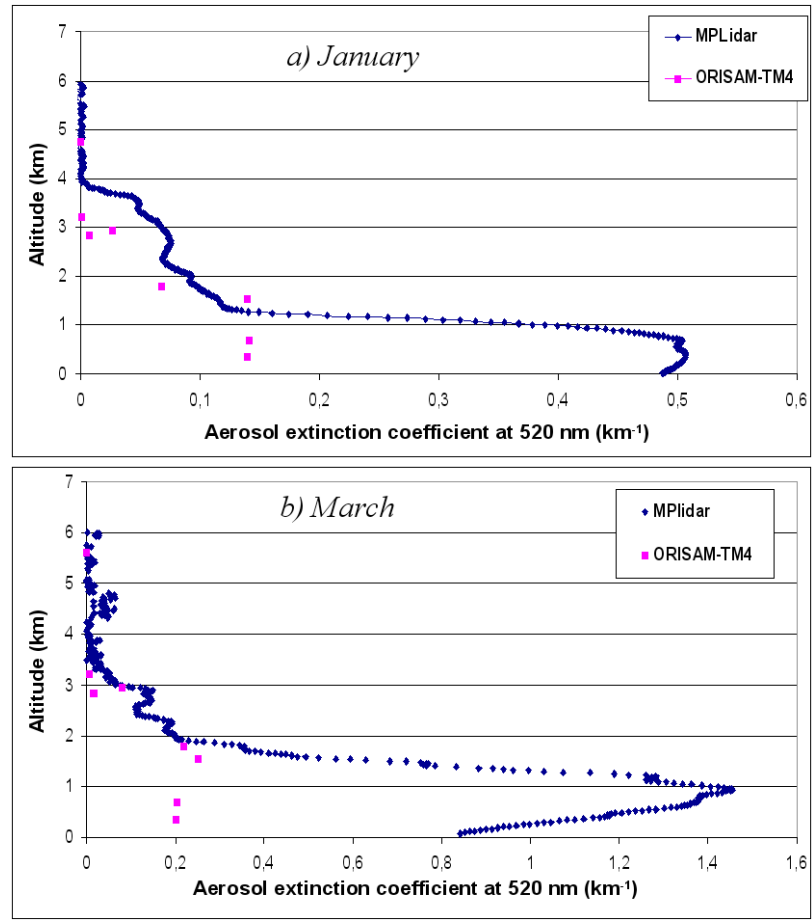

Fig. 8. Measured (AMMA-EOP, MPLidar) and modeled (ORISAM-TM4) vertical distribution of extinction coefficients at Djougou (Benin) in (a) January and in (b) March at $523 \mathrm{~nm}$.

\subsubsection{Spatial distribution of aerosol optical depth over Africa}

We further compared spatial distributions of simulated AOD over Africa data from the PARASOL satellite (http://www. icare.univ-lille1.fr/parasol/browse/, Fig. 9b and d (right) for the model, and 9a and c for PARASOL (left)), for January 2006 (top) and July 2006 (bottom). Note that the aerosol optical depths in the PARASOL data are derived at $0.86 \mu \mathrm{m}$, leading to lower estimates of aerosol optical depths than those derived from sun-photometers (Fig. 7) owing to strong wavelength dependence of the aerosol optical depth typical of biomass burning aerosols. Model simulated and observed AOD are of the same order of magnitude. This study shows that the use of updated biomass burning emissions in a global model including a complex aerosol module with core/shell optical treatment can produce quite satisfactory results. Regional patterns simulated by the model are in agreement with satellite data, both in January (biomass burning in the Northern Hemisphere) and in July (biomass burning in the Southern Hemisphere). However, in our work there are still two obvious discrepancies. First, the maximum simulated AOD occurs too far eastwards in January, and second, in July, the simulated AOD maximum occurs over a larger area, extending further southwards than observed. We evaluated the impact of the AMMABB in-
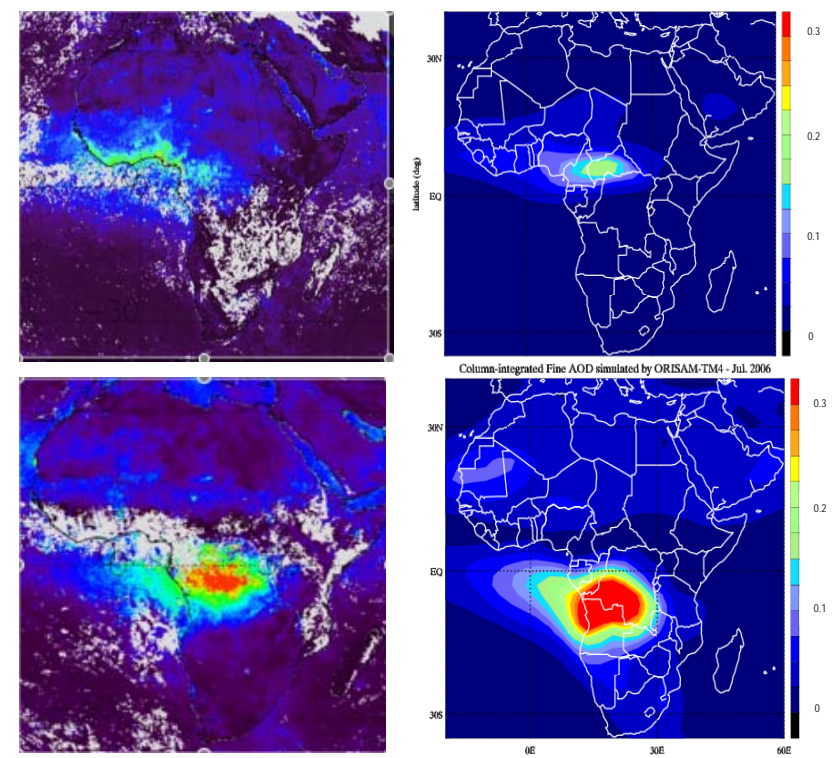

Fig. 9. Observed (PARASOL data, left) and modeled (ORISAMTM4, right) fine aerosol optical depths over Africa in January 2006 (top) and July 2006 (bottom) at $860 \mathrm{~nm}$.

ventory in terms of these differences. In January, satellite data indicates hot spots along the Guinean gulf, which are not captured in the model, and which are likely explained by fossil fuel sources since biomass burning emissions are not present at these locations (e.g. http://modis-fire.umd.edu/ images/MCD45_1year_World.jpg). Further tests are required using the updated regional African fossil fuel inventories of Assamoi and Liousse, 2010 in order to assess whether these points can be reproduced in the model. Note that Johnson et al. (2008) provides an assessment of the geographic distribution of aerosol optical depths from biomass burning aerosol using GFED1 data and the HadGEM2 global model for January 2006 with a strikingly similar spatial distribution to that modeled here for the same time period (Fig. 7a of their work).

The southwestwards displacement of AOD maximum simulated by our model in July 2006 can possibly be explained by errors in the location of biomass burning, errors in the simulated transport of these aerosol or errors in the AOD satellite products themselves. It is interesting to note that another study investigating the influence of the transport of biomass burning aerosol from Southern to Western Africa in July with TM4 model (Williams et al., 2010) also shows that the model does not accurately reproduce West African $\mathrm{CO}$ and ozone concentrations as compared to observations. A northern shift of simulated concentrations would help to improve West African comparisons. Furthermore, a similar southward displacement of AOD maximum was observed when the AMMABB inventory was incorporated in the RegCM3 regional model (Tummon et al., 2010). In addition, Tummon et al. (2010), tested the sensitivity of RegCM3 
to the GFED2 biomass burning inventory in order to assess the difference between the AMMABB and GFED2 inventories. No improvement in the location of AOD maximum was observed and comparisons with satellite data in fact showed that simulations using the AMMABB inventory reproduced the magnitude of AOD better (Tummon et al., 2010). Finally, this shift, also seen when comparing simulated AOD to MODIS satellite observations (http://modis.gsfc.nasa.gov/) (not shown here), could be due to errors in satellite retrievals as well. The next generation of biomass burning inventories using both burnt areas, fire radiance energy and dynamical vegetation models will hopefully contribute to understanding such complex issue (Wooster et al., 2002, 2005, Ichoku and Kaufman, 2005).

\section{Conclusion}

We developed a daily African biomass burning inventory for the 2000-2007 period at $1 \mathrm{~km} \times 1 \mathrm{~km}$ horizontal spatial resolution, for gaseous and particulate species. This inventory was then compared to other existing inventories. A factor of $\sim 2.4$ of differences between GFED2 and AMMABB inventories may be found, which is reasonable, considering the large uncertainties inherent in the determination of biomass burning emissions (Stroppiana et al., 2010). The inventory was also tested within the ORISAM-TM4 global model for $\mathrm{BC}$ particle emissions. Comparisons were made with surface, column-integrated and satellite observations obtained during the AMMA campaign. Major features appear to be well reproduced by the global model when the updated biomass burning emissions are included. Seasonal variability of modeled $\mathrm{BC}$ concentrations is well simulated at the three AMMA super-sites, Djougou, Lamto and Banizoumbou. Satisfactory comparisons are also obtained with surface measurements of scattering coefficients, sunphotometer AOD and column-integrated SSA values at the Djougou and Banizoumbou sites. Major problems appear to be related to coarse model grid resolution, which does not capture local intense biomass burning events, and to dust modeling, which still requires further development. Similar underestimations (Malavelle et al., 2009) are also found using RegCM3 regional model implemented with the same dust scheme as ORISAM-TM4. Comparison with PARASOL aerosol optical depth data shows good agreement in terms of AOD magnitudes, though maximum AOD are shifted too far eastwards in January and too far southwards in July. These results are in favor of the existence of strong additional particulate source along the Guinean gulf coast, possibly related to developing megacities, industrial and oil activities there, this source not yet being fully accounted for in current inventories. Finally, AMMABB emission inventories appear to be systematically higher than GFED ones. As already noted by different papers, such a difference in source is required to improve the agreement between observations and models. This is the case in West Africa with HADGEM2 model (Johnson et al., 2008) and with RegCM3 model (Tummon et al., 2010) for Southern Africa. Similar improvement has been also reported in AMMA model inter-comparisons for the gas components of the AMMABB product (Barret et al., 2010).

Acknowledgements. Based on a French initiative, AMMA was built by an international scientific group and is currently funded by a large number of agencies, especially from France, the United Kingdom, the United States, and Africa. It has been the beneficiary of a major financial contribution from the European Community's Sixth Framework Research Programme. Detailed information on scientific coordination and funding is available on the AMMA international website at www.amma-international.org.

\section{Edited by: C. Reeves}

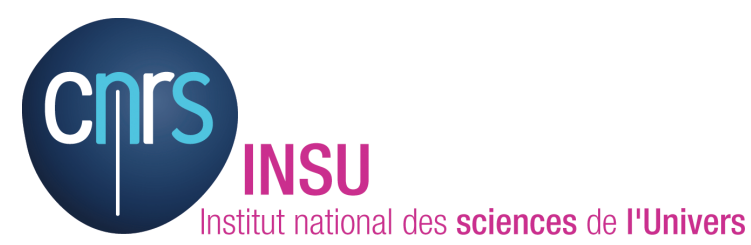

The publication of this article is financed by CNRS-INSU.

\section{References}

Alfaro, S. C., Lafon, S., Rajot, J. L., Formenti, P., Gaudichet, A., and Maillé, M.: Iron oxides and light absorption by pure desert dust : an experimental study, J. Geophys. Res. 109, D08208, doi:10.1029/2003JD004374, 2004.

Andreae, M. O. and Merlet, P.: Emission of trace gases and aerosols from biomass burning, Global Biogeochem. Cy., 15, 955-966, 2001.

Assamoi, E. and Liousse, C.: Focus on the impact of two wheel vehicles on African combustion aerosols emissions, Atmos. Environ. 44, 3985-3996, 2010

Barret B., Williams, J. E., Bouarar, I., Yang, X., Josse, B., Law, K., Pham, M., Le Flochmoen, E., Liousse, C., Peuch, V. H., Carver, G. D., Pyle, J. A., Sauvage, B., van Velthoven, P., Schlager, H., Mari, C., and Cammas, J.-P.: Impact of West African Monsoon convective transport and lightning $\mathrm{NO}_{\mathrm{x}}$ production upon the upper tropospheric composition: a multi-model study, Atmos. Chem. Phys., 10, 5719-5738, doi:10.5194/acp-10-57192010, 2010.

Bauer, S. E., Balkanski, Y., Schulz, M., Hauglustaine, D. A., and Dentener, F.: Global modeling of heterogeneous chemistry on mineral aerosol surfaces: Influence on tropospheric ozone chemistry and comparison to observations, J. Geophys. Res., 109, D02304, doi:10.1029/2003JD003868, 2004.

Bauer, S. E., Menon, S., Koch, D., Bond, T. C., and Tsigaridis, K.: A global modeling study on carbonaceous aerosol microphysical characteristics and radiative effects, Atmos. Chem. Phys., 10, 7439-7456, doi:10.5194/acp-10-7439-2010, 2010.

Bessagnet, L., Menut, G., Curci, A., Hodzic, B., Guillaume, C., Liousse, S., Moukhtar, B., Pun, Seigneur, C., and Schulz, M.: 
Regional modeling of carbonaceous aerosols over Europe- focus on secondary organic aerosols, J. Atmos Chem., 61(3), doi:10.1007/s10874-009-9129-2, 2009.

Bond, T. C.,. Anderson, T. L., and Campbell, D.: Calibration and intercomparison of filter-based measurement of light absorption by aerosols, Aerosol Sci. Technol., 30, 582-600, 1999.

Bowen, H. J. M.: Trace elements in biogeochemistry, Academic Press, London, UK, 241 pp. 1966.

Capes, G., Murphy, J. G., Reeves, C. E., McQuaid, J. B., Hamilton, J. F., Hopkins, J. R., Crosier, J., Williams, P. I., and Coe, H.: Secondary organic aerosol from biogenic VOCs over West Africa during AMMA, Atmos. Chem. Phys., 9, 3841-3850, doi:10.5194/acp-9-3841-2009, 2009.

Carmichael, G. R., Adhikary, B., Kulkarni, S., D’Allura, A., Tang, Y., Streets, D., Zhang, Q., Bond, T., Ramanathan, V., Jamroensan, A., and Marrapu, P.: Asian aerosols: current and year 2030 distributions and implications to human health and regional climate change, Environ. Sci. Technol. 43, 5811-5817, 2009.

Chin, M., Ginoux, P., Kinne, S., Torres, O., Holben, B. N., Duncan, B. N., Martin, R. V., Logan, J. A., Higurashi, A., and Nakajima, T.: Tropospheric Aerosol Optical Thickness from the GOCART Model and Comparisons with Satellite and Sun Photometer Measurements, J. Atmos. Sci., 59, 461-483, 2002.

Chou, C., Formenti, P., Maille, M., Ausset, P., Helas, G., Harrison, M., and Osborne, S.: Size distribution, shape, and composition of mineral dust aerosols collected during the African Monsoon Multidisciplinary Analysis Special Observation Period 0: Dust and Biomass-Burning Experiment field campaign in Niger, January 2006, J. Geophys. Res., 113, D00C10, doi:10.1029/2008JD009897, 2008.

Collaud Coen, M., Weingartner, E., Apituley, A., Ceburnis, D., Fierz-Schmidhauser, R., Flentje, H., Henzing, J. S., Jennings, S. G., Moerman, M., Petzold, A., Schmid, O., and Baltensperger, U.: Minimizing light absorption measurement artifacts of the aethalometer: evaluation of five correction algorithms, Atmos. Meas. Tech., 3, 457-474, doi:10.5194/amt-3-457-2010, 2010.

Cooke, W. F., Koffi, B. and Grégoire, J. M.: Seasonality of vegetation fires in Africa from remote sensing data and application to a global chemistry model, J. Geophys. Res., 101, 21051-21065, 1996.

Cooke, W. F., Liousse, C., Cachier, H., Feichter, J.: Construction of a $1^{\circ} \times 1^{\circ}$ fossil-fuel emission dataset for carbonaceous aerosol and implementation en the ECHAM4 model, J. Geophys. Res., 104, 22137-22162, 1999.

Cousin, F., Liousse, C., Cachier, H., Bessagnet, B., Guillaume, B., and Rosset, R.: Aerosol modelling and validation during Escompte 2001, Atmos. Environ., 39(8), 1539-1550, 2005.

Crumeyrolle, S., Gomes, L., Tulet, P., Matsuki, A., Schwarzenboeck, A., and Crahan, K.: Increase of the aerosol hygroscopicity by cloud processing in a mesoscale convective system: a case study from the AMMA campaign, Atmos. Chem. Phys., 8, 6907-6924, doi:10.5194/acp-8-6907-2008, 2008.

Curtis, L., Rea, W., Smith-Willis, P., Fenyves, E., and Pan, Y.: Adverse health effects of outdoor pollutants, Environ. Int., 32, 815830, 2006.

Delmas, R. A., Druilhet, A., Cros, B., Durand, P., Delon, C., Lacaux, J. P., Brustet, J. M., Serça, D., Affre, C., Guenther, A., Greenberg, J., Baugh, W., Harley, P., Klinger, L., Ginoux, P., Brasseur, G., Zimmerman, P. R., Grégoire, J. M., Janodet, E.,
Tournier, A., Perros, P., Marion, T., Gaudichet, A., Cachier, H., Ruellan, S., Masclet, P., Cautenet, S., Poulet, D., Boukabiona, C., Nganga, D., Tathy, J. P., Minga, A., Loemba-Ndembi, J., and Ceccato, P.: Experiment for Regional Sources and Sinks of Oxidants (EXPRESSO) : An overview : Experiment for regional sources and sinks of oxidants (EXPRESSO), J. Geophys. Res., 104, 30609-30624, 1999.

Delon, C., Galy-Lacaux, C., Boone, A., Liousse, C., Sera, D., Adon, M., Diop, B., Akpo, A., Lavenu, F., Mougin, E., and Timouk, F.: Atmospheric nitrogen budget in Sahelian dry savannas, Atmos. Chem. Phys., 10, 2691-2708, doi:10.5194/acp-10-26912010, 2010.

Dentener, F. J. and Crutzen, P. J.: Reactions of $\mathrm{N}_{2} \mathrm{O}_{5}$ on tropospheric aerosols: Impact on the global distributions of $\mathrm{NO}_{\mathrm{x}}, \mathrm{O}_{3}$, and OH, J. Geophys. Res., 98(D4), 7149-7163, 1993.

Dentener, F. J. and Crutzen, P. J.: A global 3D model of the ammonia cycle, J. Atmos. Chem., 19, 331-369, 1994.

Derimian, Y., Leon, J.-F., Dubovik, O., Chiapello, I., Tanre, D., Sinyuk, A., Auriol, F., Podvin, T., Brogniez, G., and Holben, B. N.: Radiative properties of aerosol mixture observed during the dry season 2006 over M'Bour, Senegal (African Monsoon Multidisciplinary Analysis campaign), J. Geophys. Res., 113, D00C09, doi:10.1029/2008JD009904, 2008.

Doumbia, T., Liousse, C., Ndiaye, S. A., and Galy Lacaux, C.: Atmospheric pollution in Dakar, Senegal: focus on the aerosol in the frame of POLCA program, AMMA Conference, Ouagadougou (Burkina), 20-25 July, 2009.

Dubovik, O., Smirnov, A., Holben, B. N., King, M. D., Kaufman, Y. J., Eck, T. F., and Slutsker, I.: Accuracy assessments of aerosol optical properties retrieved from Aerosol Robotic Network (AERONET) Sun and sky radiance measurements, J. Geophys. Res., 105, 9791-9806, 2000.

Fialho, P., Hansen, A. D. A., and Honrath, R. E.: Absorption coefficients by aerosols in remote areas: a new approach to decouple dust and black carbon absorption coefficients using sevenwavelength Aethalometer data, J. Aerosol Sci., 36(2), 267-282, 2005.

Formenti, P., Winkler, H., Fourie, P., Piketh, S., Makgopa, B., Helas, G., and Andreae, M. O.: Aerosol optical depth over a remote semi-arid region of South Africa from spectral measurements of the daytime solar extinction and the nighttime stellar extinction, Atmos. Res., 62, 11-32, 2002.

Galy-Lacaux, C., Carmichael, G. R., Song, C. H., Lacaux, J. P., Al Ourabi, H., and Modi, A. I.: Heterogeneous processes involving nitrogenous compounds and Saharan dust inferred from measurements and model calculations, J. Geophys. Res., 106(D12), 12559-12578, 2001.

Galy, C., Liousse, C., Mallet, M., Pont, V., Dungall, L., Sigha, L., Yoboué, V., Gardrat, E., Castéra, P., Ouafo, M., Mariscal, A., Serça, D., Poirson, A., Akpo, A., Cachier, H., Blarel, L., and Jankowiak, I.: LOP and EOP Ground-based Measurements: Characterization of Physico-chemical properties of the African Aerosol, 2nd international AMMA conference, Karlsruhe, Germany, December 2007.

Galy-Lacaux, C., Laouali, D., Descroix, L., Gobron, N., and Liousse, C.: Long term precipitation chemistry and wet deposition in a remote dry savanna site in Africa (Niger), Atmos. Chem. Phys., 9, 1579-1595, doi:10.5194/acp-9-1579-2009, 2009.

Gardner, R. M., Adams, K., Cook, T., Deidewig, F., Ernedal, S., 
Falk, R., Fleuti, E., Hermsg, E., Johnson, C. E., Lecht, M., Lee, D. S., Leech, M., Lister, D., Massé, B., Metcalfe, M., Newton, P., Schmitt, A., Vandenbergh, C., and van Drimmelen, R.: The ANCAT/EC global inventory of $\mathrm{NO}_{\mathrm{x}}$ emissions from aircraft, Atmos. Environ., 31, 1751-1766, 1997.

Ghan, S., Laulainen, N., Easter, R., Wagener, R., et al.: Evaluation of aerosol direct radiative forcing in MIRAGE, J. Geophys. Res., 106(D6), 5295-5316, 2001

Gelbard, F., Tambour, Y. and Seinfeld, J. H.: Sectional representation for simulating aerosol dynamics. J. Colloid Interface Sci., 76, 541-556, 1980.

Generoso, S., Bey, I., Attie, J. L., and Breon, F. M.: A satellite and model-based assessment of the 2003 Russian fires: inpact on the Artic region., J. Geophys. Res., 112, D15302, doi:10.1029/2006JD008344, 2007.

Gong, S. L., Barrie, L. A., and Blanchet, J.-P.: Modeling sea-salt aerosols in the atmosphere. 1. Model development, J. of Geophys. Res., 102(D3), 3805-3818, 2003.

Granier, C., Lamarque, J. F., Mieville, A., Muller, J. F., Olivier, J., Orlando, J., Peters, J., Petron, G., Tyndall, G., and Wallens, S.: POET, a database of surface emissions of ozone precursors, available online at: http://www.aero.jussieu.fr/projet/ACCENT/ POET.php, 2005.

Grégoire, J.-M., Tansey, K., and Silva, J. M. N.: The GBA2000 initiative: Developing a global burned area database from SPOTVEGETATION imagery, Int. J. Remote Sens., 24(6), 1369-1376, 2002.

Guillaume, B., Liousse, C., Rosset, R., Cachier, H., Bessagnet, B., Velthoven, P. V., Poisson, N., Global modelling of internally mixed size-resolved inorganic/organic aerosols with a focus on carbonaceous components. Tellus, B, 9, 283-302, 2007.

Haywood, J. M., Pelon, J., Formenti, P., Bharmal, N., Brooks, M., Capes, G., Chazette, P., Chou, C., Christopher, S., Coe, H., Cuesta, J., Derimian, Y., Desboeufs, K., Greed, G., Harrison, M., Heese, B., Highwood, E. J., Johnson, B., Mallet, M., Marticorena, B., Marsham, J., Milton, S., Myhre, G., Osborne, S. R., Parker, D. J., Rajot, J.-L., Schulz, M., Slingo, A., Tanre, D., and Tulet, P.: Overview of the Dust and Biomass-burning Experiment and African Monsoon Multidisciplinary Analysis Special Observing Period-0, J. Geophys. Res., 113, D00C17, doi:10.1029/2008JD010077, 2008.

Hoelzemann, J. J., Schultz, M. G., Brasseur, G. P., Granier, C., and Simon, M.: Global Wildland Fire Emission Model (GWEM): Evaluating the use of global area burnt satellite data, J. Geophys. Res., 109, D14504, doi:10.1029/2003JD003666, 2004.

Ichoku C. and Kaufman, Y. J.: A method to derive smoke emission rates from MODIS fire radiative energy measurements, IEEE Trans. Geosci. Remote Sens., 43, 2636-2649, 2005.

Ito, A. and Penner, J. E.: Global estimates of biomass burning emissions based on satellite imagery for the year 2000, J. Geophys. Res., 109, D14S05, doi:10.1029/2003JD004423, 2004.

Jacobson, M. Z.: Global direct radiative forcing due to multicomponent anthropogenic and natural aerosols, J. Geophys. Res., 106, 1551-1568, 2001.

Janhäll, S., Andreae, M. O., and Pöschl, U.: Biomass burning aerosol emissions from vegetation fires: particle number and mass emission factors and size distributions, Atmos. Chem. Phys., 10, 1427-1439, doi:10.5194/acp-10-1427-2010, 2010.

Jain, A. K.: Global estimation of CO emissions using three sets of satellite data for burned area, Atmos. Environ., 41, 6931-6940, 2007.

Johnson, B. T., Heese, B., McFarlane, S. A., Chazette, P., Jones, A., and Bellouin, N.: Vertical distribution and radiative effects of mineral dust and biomass burning aerosol over West Africa during DABEX, J. Geophys. Res., 113, D00C12, doi:10.1029/2008JD009848, 2008.

Hansen A.D.A., H. Rosen, and T. Novakov, "Real-time measurement of the absorption coefficient of aerosol particles," Appl. Opt. 21, 3060-3062, 1982.

Hao, W. M., Liu, M. H., and Crutzen, P. J.: Estimates of annual and regional releases of $\mathrm{CO}_{2}$ and other trace gazes to the atmosphere from fires in the tropics, based on the FAO Statistics for the period 1975-1980, in: Fire in the Tropical Biota, Goldammer, J. C., 440-462, 1990.

Hao, W. M. and Liu, M.-H.: Spatial and temporal distribution of tropical biomass burning, Global Biogeochem. Cy., 8, 495-503, 1995.

Hodzic, A., Vautard, R., Chepfer, H., Goloub, P., Menut, L., Chazette, P., Deuze, J., Apituley, A., and Couvert, P.: Evolution of aerosol optical thickness over Europe during the August 2003 heat wave as seen from CHIMERE model simulations and POLDER data, Atmos. Chem. Phys. 6, 1853-1864, doi:10.5194/acp-6-1853-2006, 2006.

Holben, B. N., Eck, T. F., Slutsker, I., Tanré, D., Buis, J. P., Setzer, A., Vermote, E., Reagan, J. A., Kaufman, Y. J., Nakajimu, T., Lavenu, F., Jankowiak, I., and Smirnov, A.: AERONET-A Federated Instrument Network and Data Archive for Aerosol Characterization, Remote Sens. Environ., 66, 1-16, 1998.

Houweling, S., Dentener, F., and Lelieveld, J.: The impact of nonmethane hydrocarbon compounds on tropospheric photochemistry, J. Geophys. Res., 103, 10673-10696, 1998.

Jacob, D. J.: Heterogeneous chemistry and tropospheric ozone, Atmos. Environ. 34, 2131-215, 2000.

Jain, A. K.: Global estimation of CO emissions using three sets of satellite data for burned area, Atmos. Environ., 41, 6931-6940, 2007.

Junker, C. and Liousse, C.: A global emission inventory of carbonaceous aerosol from historic records of fossil fuel and biofuel consumption for the period 1860-1997, Atmos. Chem. Phys., 8, 1195-1207, doi:10.5194/acp-8-1195-2008, 2008.

Kaufman, Y. J., Tanré, D., Holben, B. N., Mattoo, S., Remer, L. A., Eck, T. F., Vaughan, J., and Chatenet, B.: Aerosol radiative impact on spectral solar flux at the surface, derived from principalplane sky measurements, J. Atmos. Sci., 59, 635-646, 2002.

Kim, S.-W., Chazette, P., Dulac, F., Sanak, J., Johnson, B., and Yoon, S.-C.: Vertical structure of aerosols and water vapor over West Africa during the African monsoon dry season, Atmos. Chem. Phys., 9, 8017-8038, doi:10.5194/acp-9-8017-2009, 2009.

Kinne, S., Schulz, M., Textor, C., Guibert, S., Balkanski, Y., Bauer, S. E., Berntsen, T., Berglen, T. F., Boucher, O., Chin, M., Collins, W., Dentener, F., Diehl, T., Easter, R., Feichter, J., Fillmore, D., Ghan, S., Ginoux, P., Gong, S., Grini, A., Hendricks, J., Herzog, M., Horowitz, L., Isaksen, I., Iversen, T., Kirkevåg, A., Kloster, S., Koch, D., Kristjansson, J. E., Krol, M., Lauer, A., Lamarque, J. F., Lesins, G., Liu, X., Lohmann, U., Montanaro, V., Myhre, G., Penner, J., Pitari, G., Reddy, S., Seland, Ø., Stier, P., Takemura, T., and Tie, X.: An AeroCom initial assessment - optical 
properties in aerosol component modules of global models, Atmos. Chem. Phys., 6, 1815-1834, doi:10.5194/acp-6-1815-2006, 2006.

Koch, D., Schulz, M., Kinne, S., McNaughton, C., Spackman, J. R., Balkanski, Y., Bauer, S., Berntsen, T., Bond, T. C., Boucher, O., Chin, M., Clarke, A., De Luca, N., Dentener, F., Diehl, T., Dubovik, O., Easter, R., Fahey, D. W., Feichter, J., Fillmore, D., Freitag, S., Ghan, S., Ginoux, P., Gong, S., Horowitz, L., Iversen, T., Kirkevåg, A., Klimont, Z., Kondo, Y., Krol, M., Liu, X., Miller, R., Montanaro, V., Moteki, N., Myhre, G., Penner, J. E., Perlwitz, J., Pitari, G., Reddy, S., Sahu, L., Sakamoto, H., Schuster, G., Schwarz, J. P., Seland, Ø., Stier, P., Takegawa, N., Takemura, T., Textor, C., van Aardenne, J. A., and Zhao, Y.: Evaluation of black carbon estimations in global aerosol models, Atmos. Chem. Phys., 9, 9001-9026, doi:10.5194/acp-9-9001-2009, 2009.

Konare, A., Liousse, C., Guillaume, B., Solmon, F., Assamoi, P., Rosset, R., Gregoire, J. M., and Giorgi, F.: Combustion particulate emissions in Africa: regional climate modeling and validation, Atmos. Chem. Phys. Discuss., 8, 6653-6681, doi:10.5194/acpd-8-6653-2008, 2008.

Kulmala, M., Laaksonen, A., and Pirjola, L., Parameterizations for sulfuric acid/water nucleation rates, J. Geophys. Res. 103, 83018308, 1998.

Lacaux, J. P., Brustet, J. M., Delmas, R., Menaut, J. C., Abbadie, L., Bonsang, B., Cachier, H., Baudet, J., Andreae, M. O., and Helas G.: Biomass burning in the tropical savannas of Ivory Coast : an overview of the field experiment fire of savannas (FOS/DECAFE 91), J. Atmos. Chem., 22, 195-216, 1995.

Lavoue, D., Liousse, C., Cachier, H., Stocks, B. J., and Goldammer, J. G.: Modeling of carbonaceous particles emitted by boreal and temperate wild-fires at northern latitudes, J. Geophys. Res., 105, 26871-26890, 2000.

Lebel, T., Parker, D. J., Flamant, C., Bourles, B., Marticorena, B., Mougin, E., Peugeot, C., Diedhiou, A., Haywood, J. M., Ngamini, J. B., Polcher, J., Redelsperger, J.-L., and Thorncroft, C. D.: The AMMA field campaigns: Multiscale and multidisciplinary observations in the West African region, Q. J. Roy. Meteorol. Soc., 136(S1), 8-33, doi:10.1002/qj.486, 2010

Léon, J.-F., Y. Derimian, I. Chiapello, D. Tanré, T. Podvin, B. Chatenet, A. Diallo, and C. Deroo, 2009: Aerosol vertical distribution and optical properties over M'Bour from 2006 to 2008 , Atmos. Chem. Phys., 9, 9249-9261, doi:10.5194/acp-9-92492009, 2009.

Lesins, G., Chylek, P., and Lohmann, U.: A study of internal and external mixing scenarios and its effet on aerosol optical properties and direct radiative forcing, J. Geophys. Res. 107, 4094, doi:10.1029/2001JD000973, 2002.

Liousse C., Cachier, H., and Jennings, S. J.: Optical and thermal measurements of black carbon aerosol content in different environments: variation of the specific attenuation cross-section, sigma (s), Atmos. Environ., 27A, 1203-1211, 1993.

Liousse, C., Penner, J. E., Chuang, C., Walton, J. J., Eddleman, H., and Cachier, H.: A global three-dimensional model study of carbonaceous aerosols, J. Geophys. Res., 105, 26871-26890, 1996.

Liousse C., Andreae, M. O., Artaxo, P., Barbosa, P., Cachier, H., Grégoire, J. M., Hobbs, P., Lavoué, D., Mouillot, F., Penner, J., and Scholes, M.: Deriving Global Quantitative Estimates for
Spatial and Temporal Distributions of Biomass Burning Emissions, In " Emissions of Atmospheric Trace Compounds ", edited by: Granier, C., Artaxo, P., and Reeves, C., Kluwer Academic Publishers, Dordrecht, The Netherlands, 544 pp., 2004.

Liousse, C., Michel, C., Bessagnet, B., Cachier, H., and Rosset, R.: 0D-Modelling of Carbonaceous Aerosols over Greater Paris focusing on the organic particle formation, J. Atmos. Chem., 51, 207-221, 2005.

Malavelle, F., Pont, V., Solmon, F., Mallet, M., Léon, J.-F., and Liousse, C.: Regional radiative impacts of mixed dust and carbonaceous aerosols over West Africa during AMMA experiment, 3rd international AMMA conference, Ouagadougou, July 2009.

Mallet, M., Pont, V., and Liousse, C.: Modelling of strong heterogeneities in aerosol single scattering albedos over a polluted regional zone, Geophys. Res. Lett., 32, L09807, doi:10.1029/2005GL022680, 2005.

Mallet, M., Pont, V., Liousse, C., Roger, J. C., and Dubuisson, P.: Simulation of aerosol radiative properties with the ORISAMRAD model during a pollution event (ESCOMPTE 2001), Atmos. Environ., 40, 7696-7705, 2006.

Mallet, M., Pont, V., Liousse, C., Gomes, L., Pelon, J., Osborne, S., Haywood, J., Dubuisson, P., Roger, J. C., Mariscal, A., Thouret, V., and Goloub, P.: Aerosol direct radiative forcing on Djougou (Benin) during the AMMA dry season experiment, J. Geophys. Res., 113, D00C01, doi:10.1029/2007JD009419, 2008.

Mallet, M., Tulet, P., Serça, D., Solmon, F., Dubovik, O., Pelon, J., Pont, V., and Thouron, O.: Impact of dust aerosols on the radiative budget, surface heat fluxes, heating rate profiles and convective activity over West Africa during March 2006, Atmos. Chem. Phys., 9, 7143-7160, doi:10.5194/acp-9-7143-2009, 2009.

Marticorena, B. and Bergametti, G.: Modeling the atmospheric dust cycle: 1. Design of a soil-derived dust emission scheme, J. Geophys. Res., 100, 16415-16430, 1995.

Marticorena, B., Haywood, J., Coe, H., Formenti, P., Liousse, C., Mallet, M., and Pelon, J.: Tropospheric aerosols over West Africa, Highlights from the AMMA international program, Atmos. Sci. Lett., submitted, 2010.

Matsuki, A., Schwarzenboeck, A., Venzac, H., Laj, P., Crumeyrolle, S., and Gomes, L.: Cloud processing of mineral dust: direct comparison of cloud residual and clear sky particles during AMMA aircraft campaign in summer 2006, Atmos. Chem. Phys., 10, 1057-1069, 2010,

http://www.atmos-chem-phys.net/10/1057/2010/.

Michel, C., Liousse, C., Grégoire, J.-M., Tansey, K., Carmichael, G. R., and Woo, J.-H.: Biomass burning emission inventory from burn area data given by the SPOT-VEGETATION system in the fram of TRACE-P and ACE-Asia campaigns, J. Geophys. Res., 110, D09304, doi:10.1029/2004JD005461, 2005.

Mieville, A., Granier, C., Liousse, C., Guillaume, B., Mouillot, F., Lamarque, J.-F., Grégoire, J.-M., and Pétron, G.: Emissions of gases and particles from biomass burning during the 20th century using satellite data and an historical reconstruction, Atmos. Environ., 44(11), 1469-1477, 2010.

Moffet, R. C. and Prather, K. A.: In situ measurements of the mixing state and optical properties of soot with implications for radiative forcing estimate, Proc. Natl. Acad. Sci., 106, 1187211877, 2009.

Myhre, G., Grini, A., Haywood, J. M., Stordal, F., Chatenet, B., Tanré, D., Sundet, J. K., and Isaksen Ivar, S. A.: Modeling the 
radiative impact of mineral dust during the Saharan Dust Experiment (SHADE) campaign : The Saharan Dust Experiment (SHADE), J. Geophys. Res., 108, SAH6.1-SAH6.13, 2003.

Myhre, G., Hoyle, C. R., Berglen, T. F., Johnson, B. T., and Haywood, J. M.: Modeling of the solar radiative impact of biomass burning aerosols during the Dust and Biomassburning Experiment (DABEX), J. Geophys. Res., 113, D00C16, doi:10.1029/2008JD009857, 2008.

Nenes, A., Pandis, S. N., and Pilinis, C.: ISORROPIA: A new thermodynamic equilibrium model for multiphase multicomponent inorganic aerosols, Aquat. Geochem., 4, 123-152, 1998,

Odum, J. R., Hoffman, T., Bowman, F., Collins, D., Flagan, R. C., and coauthors: Gas-particle partitioning and secondary aerosol yield, Environ. Sci. Tech., 30, 2580-2585, 1996.

Olivier, J. G. J, A. F. Bouwman, J. J. M. Berdowski, C. Veldt, J. P. J. Bloos, A. J. H. Visschedijk, C. W. M. van der Maas, P. Y. J. Zandveld: Sectoral emission inventories of greenhouse gases for 1990 on a per country basis as well as on $1^{\circ} \times 1^{\circ}$ degrees, Environ. Sci. Pol., 2, 241-263, 1999.

Osborne, S. R., Johnson, B. T., Haywood, J. M., Baran, A. J., Harrison, M. A. J., and McConnell, C. L.: Physical and optical properties of mineral dust aerosol during the Dust and Biomass-burning Experiment, J. Geophys. Res., 113, D00C03, doi:10.1029/2007JD00955, 2008.

Pelon, J., Mallet, M., Mariscal, A., Goloub, P., Tanre, D., Bou Karam, D., Flamant, C., Haywood, J., Pospichal, B., and Victori, S.: Microlidar observations of biomass burning aerosol over Djougou (Benin) during African Monsoon Multidisciplinary Analysis Special Observation Period 0: Dust and Biomass-Burning Experiment, J. Geophys. Res., 113, D00C18, doi:10.1029/2008JD009976, 2008.

Péré, J. C., Mallet, M., Bessagnet, B., and Pont, V.: Evidence of the aerosol core-shell mixing state over Europe by using CHIMERE simulations and AERONET inversions, Geophys. Res. Lett., 36, L09807, doi:10.1029/2009GL037334, 2009.

Péré, J. C., Mallet, M., Pont, V., and Bessagnet, B.: Evaluation of a new aerosol optical scheme in the chemistry-transport model CHIMERE using ground-based AERONET and satellite measurements, Atmos. Environ., 44(30), 3688-3699, 2010.

Pétron, G., Granier, C., Khattatov, B., Yudin, V., Lamarque, J.-F., Emmons, L., Gille, J., and Edwards, D. P.: Monthly CO surface sources inventory based on the 20002001 MOPITT satellite data, Geophys. Res. Lett., 31, L21107, doi:10.1029/2004GL020560, 2004.

Petzold, A., Kopp, C., and Niessner, R.: The dependence of the specific attenuation cross section on black carbon mass fraction and particle size, Atmos. Environ., 31, 661-672, 1997.

Pinker, R. T., Liu, H., Osborne, S. R., and Akoshile, C.: Radiative Effects of Aerosols in sub-Sahel Africa: Dust and Biomass Burning, J. Geophys. Res., 115, D15205, doi:10.1029/2009JD013335, 2010.

Pont V., Mallet, M., Liousse, C., Gomes, L., Malavelle, F., Solmon, F., Galy, C., Gardrat, E., and Castéra, P.: Mixing of dust and carbonaceous aerosols: three concepts of chemical scheme from AMMA dry season experiment (SOP 0 - January 2006) at Djougou (Benin), AMMA Conférence, Ouagadougou (Burkina), 20-25 July 2009.

Prospero, J. M., Ginoux, P., Torres, O., Nicholson, S. E., and Gill, T. E.: Environmental characterization of global sources of at- mospheric soil dust identified with the NIMBUS7 total ozone mapping spectrometer(TOMS) absorbing aerosol product, Rev. Geophys., p. 1002, doi:10.1029/2000RG000095, 2002.

Rajot, J. L., Formenti, P., Alfaro, S., Desboeufs, K., Chevaillier, S., Chatenet, B., Gaudichet, A., Journet, E., Marticorena, B., Triquet, S., Maman, A., Mouget, N., and Zakou, A.: AMMA dust experiment: An overview of measurements performed during the dry season special observation period (SOP0) at the Banizoumbou (Niger) supersite, J. Geophys. Res., 113, D00C14, doi:10.1029/2008JD009906, 2008.

Raut, J.-C. and Chazette, P.: Radiative budget in the presence of multi-layered aerosol structures in the framework of AMMA SOP-0, Atmos. Chem. Phys., 8, 6839-6864, doi:10.5194/acp-86839-2008, 2008.

Sauvage B., Thouret, V., Cammas, J.-P., Brioude, J., Nedelec, P., and Mari, C.: Meridional ozone gradients in the African upper troposphere, Geophys. Res. Lett., 34, L03817, doi:10.1029/2006GL028542, 2007.

Serça, D., Lohou, F., Pospischal, B., Blarel, L., Cachier, H., Campistron, B., Castera, P., Crewell, S., Galle, S., Galy-Lacaux, C., Goloub, P., Liousse, C., Gardrat, E., Gosset, M., Goutail, F., Mallet, M., Mariscal, A., Pelon, J., Poirson, A., Pont, V., Sciare, J., and Tanré, D., EOP ground-based measurements at the Nangatchori (Benin) AMMA site: a seasonal overview, 2nd international AMMA conference, Karlsruhe, Germany, December, 2007.

Slingo, A., Ackerman, T. P., Allan, R. P., et al.: Observations of the impact of a major Saharan dust storm on the atmospheric radiation balance, Geophys. Res. Lett., 33, L24817, doi:10.1029/2006GL027869, 2006.

Solmon F., Mallet, M., Elguindi, N., Giorgi, F., Zakey, A., and Konaré, A.: Dust aerosol impact on regional precipitation over western Africa, mechanisms and sensitivity to absorption properties, Geophys. Res. Lett., 35, L24705, doi:10.1029/2008GL035900, 2008.

Stier, P., Feichter, J., Kinne, S., Kloster, S., Vignati, E., Wilson, J., Ganzeveld, L., Tegen, I., Werner, M., Balkanski, Y., Schulz, M., Boucher, O., Minikin, A., and Petzold, A.: The aerosolclimate model ECHAM5-HAM, Atmos. Chem. Phys., 5, 11251156, doi:10.5194/acp-5-1125-2005, 2005.

Stroppiana, D., Brivio, P. A., Grégoire, J.-M., Liousse, C., Guillaume, B., Granier, C., Mieville, A., and Chin, M.: Comparison of global monthly $\mathrm{CO}$ emission maps derived from remotely sensed burned area datasets, Atmos. Chem. Phys. Discuss., 10, 17657-17697, 2010, http://www.atmos-chem-phys-discuss.net/10/17657/2010/.

Swap, R. J., Annegarn, H. J., Suttles, J. T., Haywood, J., Helmlinger, M. C., Hely, C., Hobbs, P. V., Holben, B. N., Ji, J., King, M. D., Landmann, T., Maenhaut, W., Otter, L., Pak, B., Piketh, S. J., Platnick, S., Privette, J., Roy, D., Thompson, A. M., Ward, D., and Yokelson, R.: The Southern African Regional Science Initiative (SAFARI 2000): overview of the dry season field campaign, South African J. Sci., 98, 125-130, 2002.

Tanré, D., Haywood, J. M., Pelon, J., Léon, J. F., Chatenet, B., Formenti, P., Francis, P., Goloub, P., Highwood, E. J., and Myhre, G.: Measurement and modeling of the Saharan dust radiative impact: overview of the SaHAran Dust Experiment (SHADE), J. Geophys. Res., 8574, 108(D13), doi:10.1029/2002JD003273, 2003. 
Tansey, K., Grégoire, J. M., Defourny, P., Leigh, R., Pekel, J. F., Van Bogaert, E., and Bartholomé, E.: A new, global, multi-annual (2000-2007) burnt area product at $1 \mathrm{~km}$ resolution, Geophys. Res. Lett., 35, L01401, doi:10.1029/2007GL031567, 2008.

Tansey, K., Grégoire, J. M., Stroppiana, D., Sousa, A., Silva, J., Pereira, J. M. C., Boschetti, L., Maggi, M., Brivio, P. A., Fraser, R., Flasse, S., Ershov, D., Binaghi, E., Graetz, D., and Peduzzi, P.: Vegetation burning in the year 2000: Global burned area estimates from SPOT vegetation data, J. Geophys Res., 109, D14S03, doi:10.1029/2003JD003598, 2004.

Tulet, P., Mallet, M., Pont, V., Pelon, J., and Boone, A.: The 7-12 March dusty storm over West Africa. Dust generation and layering, J. Geophys. Res., 113, D00C08, doi:10.1029/2008JD009871, 2008.

Tummon, F., Solmon, F., Liousse, C., and Tadross, M.: Simulation of the direct and semidirect aerosol effects on the southern Africa regional climate during the biomass burning season, J. Geophys. Res., 115, D19206, doi:10.1029/2009JD013738, 2010.

Uppala, S., Kalberg, P. W., Simmons, A. J., et al.: The ERA40 re-analysis, Q. J. Roy. Meteorol. Soc. 131, 2961-3012, doi:10.1256/qj.04.176, 2005.

Van der Werf, G. R.: GFED2 updates for 2005-2008, http://www. falw.vu/ $\sim$ gwerf/GFED/index.html, 2008.

Van der Werf, G. R., Randerson, J. T., Giglio, L., Collatz, G. J., Kasibhatla, P. S., and Arellano Jr., A. F.: Interannual variability in global biomass burning emissions from 1997 to 2004, Atmos. Chem. Phys. 6, 3423-3441, 2006.
Van Velthoven P. F. J. and Kelder, H.: Estimates of StratosphereTroposphere Exchange: Sensitivity to model formulation and horizontal resolution, J. Geophys. Res., 101, 1429-1434, 1996,

Williams J. E., Scheele, M. P., van Velthoven, P., Bouarar, I., Law, K., Josse, B., Peuch, V.-H., Yang, X., Pyle, J., Thouret, V., Barret, B., Liousse, C., Hourdin, F., Szopa, S., and Cozic, A.: Global Chemistry simulations in the AMMA Multimodel Intercomparison Project, Bull. Am. Meteorol. Soc., 611-624, 2010.

Wooster, M. J.: Small-scale experimental testing of fire radiative energy for quantifying mass combusted in natural vegetation fires, Geophys. Res. Lett., 29(21), 2027, doi:10.1029/2002GL015487, 2002.

Wooster, M. J., Roberts, G., Perry, G. L. W., and Kaufman, Y. J.: Retrieval of biomass combustion rates and totals from fire radiative power observations: FRP derivation and calibration relationships between biomass consumption and fire radiative energy release, J. Geophys. Res., 110, D24311, doi:10.1029/2005JD006318, 2005.

Zakey, A. S., Solmon, F., and Giorgi, F.: Implementation and testing of a desert dust module in a regional climate model, Atmos. Chem. Phys., 6, 4687-4704, doi:10.5194/acp-6-4687-2006, 2006. 